\title{
Bamboos: From Bioresource to Sustainable Materials and Chemicals
}

\author{
Austine Ofondu Chinomso Iroegbu ${ }^{1,2}$ (D) and Suprakas Sinha Ray $1,2, *$ (D) \\ 1 Centre for Nanostructures and Advanced Materials, DSI-CSIR Nanotechnology Innovation Centre, Council \\ for Scientific and Industrial Research, Pretoria 0001, South Africa \\ 2 Department of Chemical Sciences, University of Johannesburg, Johannesburg 2028, South Africa \\ * Correspondence: rsuprakas@csir.co.za or ssinharay@uj.ac.za
}

check for updates

Citation: Iroegbu, A.O.C.; Ray, S.S. Bamboos: From Bioresource to Sustainable Materials and Chemicals. Sustainability 2021, 13, 12200. https:/ / doi.org/10.3390/su132112200

Academic Editors: Maria L. Auad and Farooq Sher

Received: 2 August 2021

Accepted: 26 October 2021

Published: 5 November 2021

Publisher's Note: MDPI stays neutral with regard to jurisdictional claims in published maps and institutional affiliations.

Copyright: (c) 2021 by the authors. Licensee MDPI, Basel, Switzerland. This article is an open access article distributed under the terms and conditions of the Creative Commons Attribution (CC BY) license (https:// creativecommons.org/licenses/by/ $4.0 /)$.

\begin{abstract}
Nature is a master engineer. From the bones of the tiniest bird to the sophisticated bioproduction of a spider's web, the works of nature are an enigma to the scientific mind. In the fields of physics, chemistry, biology, and mathematics, studying, understanding, and harnessing the intricacies of nature's designs for the benefit of mankind is the bedrock of science and technology. One such exceptionally engineered natural material is the bamboo plant. This ancient vegetation has, over dozens of generations, reinvented itself as a legendary, resilient, ubiquitous, and impressive bioresource that is not just sustainable, but also ecologically and cheaply cultivatable, and invaluable for soil erosion control, while holding the enormous potential to be transmuted into various useful chemicals and materials. With the increasing concerns and obligations in rethinking the future of the environment, sequestration of carbon dioxide, reduction in timber usage, and preservation of already depleted non-renewable resources, it has become vital for environmentalists, governments, scientists, and other stakeholders to identify alternatives to fossil-based chemicals and their derivable materials that are sustainable without compromising efficiency. By coalescing engineering-, chemical-, and materials science-based approaches, including results from over 100 reports, we demonstrate that the bamboo plant presents enormous opportunities for sustainable chemicals and materials. In addition, we highlight the current challenges involving the optimization of bamboo-based technologies and provide recommendations for future studies.
\end{abstract}

Keywords: bioresources; lignocellulosic biomass; carbon sink; bamboo plant; sustainable chemicals; sustainable construction; bioeconomy

\section{Introduction}

Notwithstanding the advances in science and technology man may have attained, nature has always proved itself a benign and ingenious creator of materials, structures, and processes that can be harnessed for man's advantage. Examples of nature's unrivalled engineering ingenuity abound all around us, demonstrating highly evolved structure-function relationships adapted to satisfy specific requirements [1-3]; for example, natural materials such as tree wood and bones (e.g., crocodilian jaws) comprise superlative composite materials that are not merely functionally engineered, but tailored to their mechanical and physical requirements while being biodegradable and benign for the environment [3-6]. A thorough assessment of naturally occurring systems, materials, and/or processes identifies certain blueprints that are fundamental in their purposeful designs and functions; these templates provide scientists, technologists, and engineers with readily available prototypes that can be copied and/or harnessed in order to meet our needs for the advancement of humankind [7-10].

One of nature's indisputable gifts to mankind is solar energy. It has been noted that the amount of energy that Earth receives from the sun in an hour surpasses all the combined energy mankind can utilize in an entire year [11]. Despite this, solar energy provides less than $1.5 \%$ of global energy needs, thereby demonstrating a vast gap between 
energy demand and this enormously underutilized clean and abundant energy source [12]. Although there has been increased research toward harnessing the sun's energy by various processes and technologies, to date, no manmade technology is comparable to the sustainable efficiency of solar energy conversion to chemical energy via photosynthesis in plants [13-16]. Indeed, studies have provided substantial evidence that photosynthesis was fundamental for Earth's oxygenation and the subsequent radiation of life $[17,18]$.

In light of the current discourse, various schools of thought maintain the view that fossil-based resources derived from nature, such as petroleum, coal, natural gas, and bitumen, are the result of geological processes on hydrocarbon matter stemming from decayed biological systems that have, directly or indirectly, converted solar energy into chemical energy, and thus, aided by the actions of heat and pressure in the earth's crust over several millenniums, produced fossilized hydrocarbons $[19,20]$. This concept sounds plausible based on the well-known first law of thermodynamics regarding the conversion of energy and matter, which stipulates that energy can neither be created nor destroyed, but can be converted from one form to another. In addition, assuming the earth is a closed system, it can be posited that this law is perhaps a self-cleaning process. Furthermore, recalling that Einstein's equation holds that $E=m c^{2}$, we can reconcile the fact that matter and energy are interchangeable [21,22]. Nevertheless, there are other schools of thought that oppose this perspective on the origins of fossil-based hydrocarbons [23,24].

For decades, fossil-based natural resources, such as petroleum, coal, natural gas, and bitumen, have remained the dominant supply for feedstocks to produce chemicals, fuels, materials, etc. In the current perspective, it is important to note that the usage of fossilbased hydrocarbons and the development of their related technologies have never been a modern concept. For example, in 1875 BC, official records of King Hammurabi's government mention the existence of the oil trade in ancient Sumeria [25]. Furthermore, in 450 BC, Herodotus described how, in Persia, oil and salt were being produced from wells and springs [25]. Then, sometime in $211 \mathrm{BC}$, while drilling for salt, natural gas was discovered in Chi-lui-ching, Szechuan, China, which was used for heating and lighting purposes [25]. Therefore, it is our view that transitioning away from fossil-based hydrocarbons may not be a process welcomed by many world governments (especially those with oil-dependent economies), due to the politics and fortunes associated with fossil-hydrocarbons [26,27]. Nevertheless, it remains inarguable that, as a result of the rising concerns regarding energy security, the protection of territorial integrities, the non-sustainability of depleting reserves of fossil-hydrocarbon resources, persistent challenges of volatile oil prices, the negative impact of greenhouse gases (GHGs), and the myriad other environmental challenges associated with fossil-based resources, that a synergized and concerted effort by governments and stakeholders, at all levels, to collaborate and forge a common front for the promotion and utilization of renewable and sustainable resources is paramount $[28,29]$. Virtually every culture known to humankind acknowledges that lignocellulosic biomass is one the oldest biorenewable resources; however, it remains strange that even today, lignocellulosic biomass is one of the least harnessed and underdeveloped natural resources in terms of optimization when compared to the technologies, chemistry, and processing involving fossilized hydrocarbons.

Taking the example of lignocellulosic biomass, Iroegbu et al. [30] noted that under $4 \%$ of the over 200 billion tons of lignocellulosic biomass produced each year is being harnessed by mankind. Coupled with the indisputable fact that the urgency for rethinking our fossil-hydrocarbon dominated world cannot be overemphasized [31-34], it has become imperative to reflect assiduously on the promise that green vegetation (e.g., lignocellulosic biomass) holds as a sustainable resource for materials, fuels, and chemicals.

Green plants such as lignocellulosic biomass are not only ubiquitous [35], but can be readily sourced from inedible and non-competitive food sources such as agricultural wastes, forestry residues, grasses, and woody materials [36,37], offering the opportunity to harvest the sun's abundant energy rather than the current capital resources represented by fossilhydrocarbons [38-40]. As previously noted, green vegetation remains the most eco-friendly, 
low carbon footprint, and resourceful solar-energy-converting machine [41,42]. In addition, plant resources as a result of natural quantum conversion processes afford vast possibilities to derive industrially applicable alternatives to hydrocarbon-based chemicals, fuels, and materials, with characteristic properties analogous to and even surpassing those of fossilbased resources [43-49]. As shown in Figure 1, the structural design and components of lignocellulosic biomass cell walls comprise a complex mix of various systems, including cellulose, lignin, hemicellulose, and other non-structural materials such as proteins [41]. These systems present chemists, materials engineers, and technologists with an assortment of derivable macro-, micro-, and nanostructured materials, including fibers, polymers, chemicals, and fuels, that are useful for modern industries (see Table 1) [39,50-56].

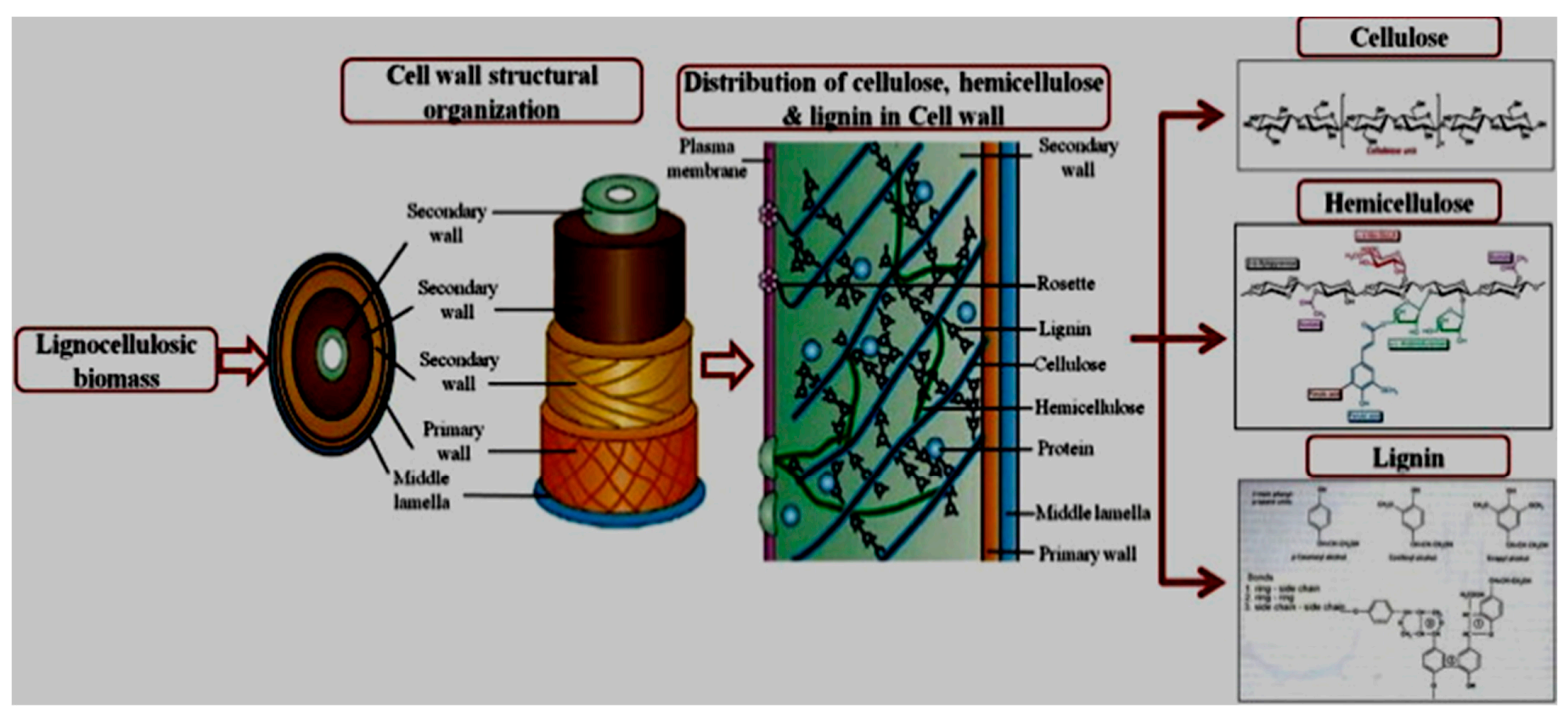

Figure 1. An overview of the structural design of lignocellulosic biomass in a plant cell wall, reprinted from ref. [43].

Table 1. Selected applications (with references) of plant cell wall components (lignocellulosic biomass) and their derivable products. Red represents cellulose, blue represents hemicellulose (xylan/pentosan), and green represents lignin. As adapted from Guerriero et al. [41].

Nanomaterials, pharmaceuticals, food, filler, fibers, cosmetics, particle board, films, gelling agent, paper, membranes, adhesives, plastics, printing inks, coatings, water remediation etc.

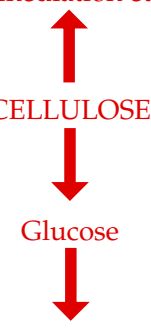

Biofuel (e.g., ethanol) Fructose sweetener, polyols, polydextrose and cyclodextrins etc.

Ref.: [48-53]
Animal feed, food, coating and packaging, adhesives, biocomposite, plastic additive, strengthening agent in paper, textile printing, nanoparticles, antiknock agents, flame retardant materials etc.

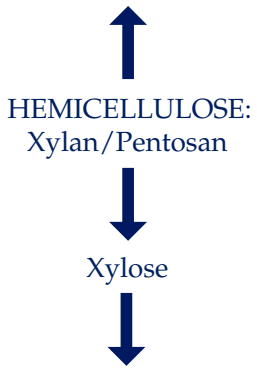

Furans and its derivatives such as Furfural (platform sundry chemical compounds such as furoic acid, tetrahydrofuran, polymers etc.), 2,5-furandicarboxylic acid (2,5-FDCA),

Furfuryl alcohol etc., enzyme catalyzed hydrogen $\left(H_{2}\right)$ production, xylitol production employed in the food and health sector, biofuel production such as ethanol, kerosene, and diesel.
Rich source of aromatic chemicals, cement additive, antioxidant, carbon nanotubes, resin, sizing agent, fuel additive, grease/lubricant production, crosslinking agent, binder/emulsifier, flocculants, soil-retention agent, dispersant, complexing agent for paints, dyes, oil-drilling muds etc.

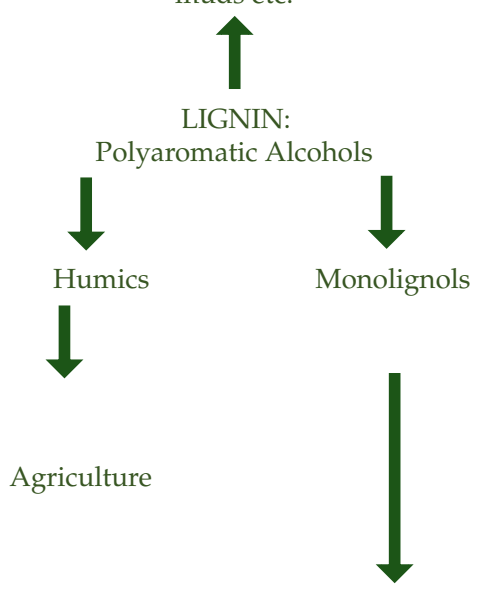

Cresols, Catechols,

Resorcinols, Quinones, Vanillin, Guaiacols Ref.: [60-77] Ref.: [30,54-59] 
Despite the current state-of-the-art research and development demonstrating the enormous inroads made to date on the valorization of lignocellulosic biomass into sustainable chemicals and materials, [44,78-83] emerging literature asserts that we have barely scratched the surface with respect to the vast application portfolios, technologies, and chemical processes, and in the understanding of the fundamental theories presented by lignocellulosic biomass valorization [72,73]. For example, the World Economic Forum noted that biobased lignin feedstock ranks amongst the top emerging technologies of the future, as it will play a significant role in the pursuits for energy security and a circular economy [74]. Moreover, the exigencies concerning our materials needs, energy, and fuel security, and the pursuit for a circular economy, whereby we are able to meet our current demands without jeopardizing those of future generations, has necessitated the need to sustain these lignocellulosic biomass supplies to meet existing and emerging global demands. One way to achieve this is to harness the vast opportunities presented by perennial plants such as the bamboos (see Figure 2), with certain species sharing the world record as the fastest-growing plants on earth; these species grow at an average of 2.92 feet per day, which translates to a rate of $0.83 \times 10^{-5} \mathrm{~m} / \mathrm{s}$ [75].

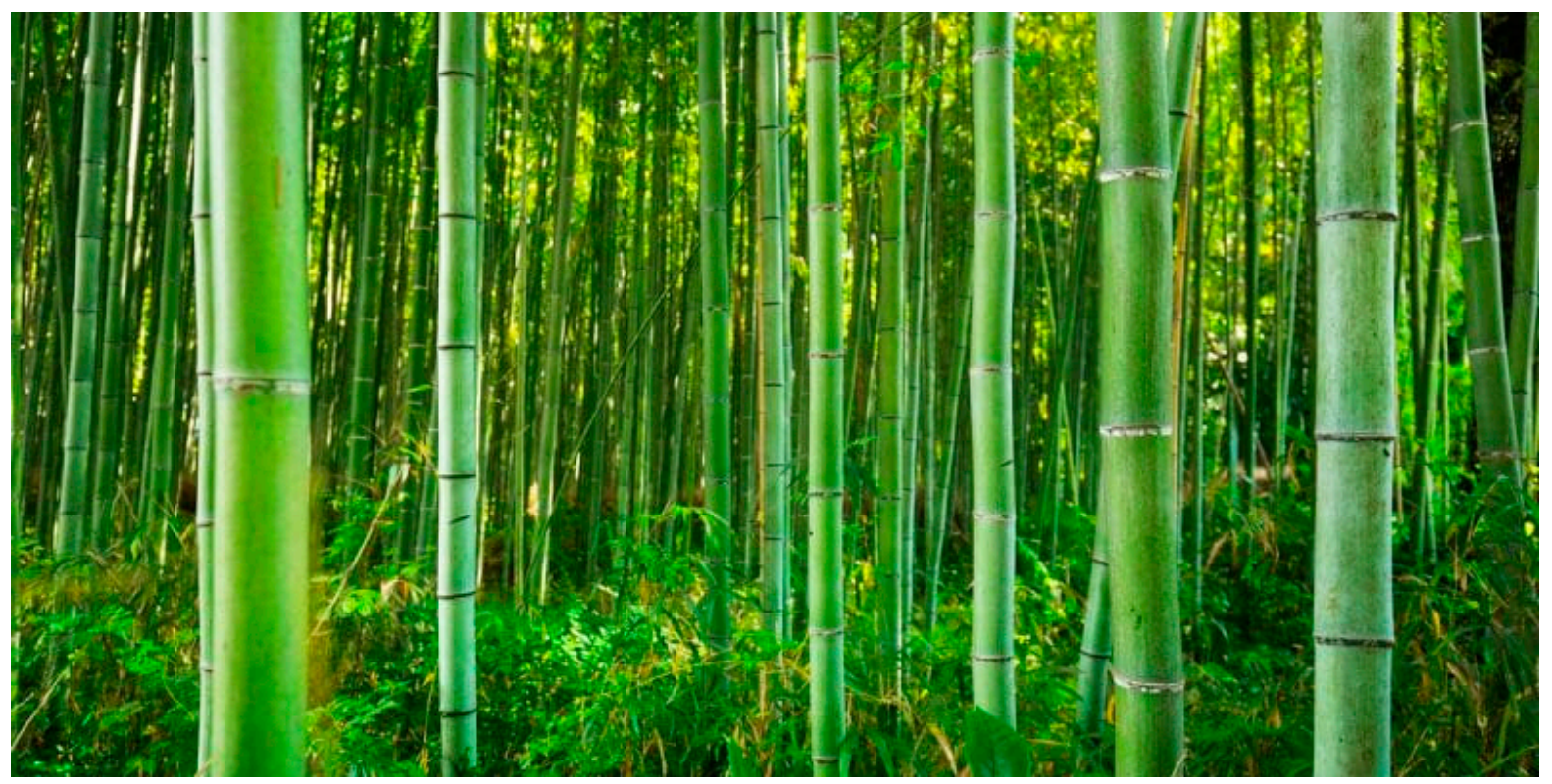

Figure 2. Bamboo plantation in Central Africa, initiated by the International Bamboo and Rattan Organisation (INBAR), aimed at helping to protect the Congo basin, combat deforestation, improve carbon sequestering, create job opportunities, and improve the local economy. Reprinted from ref. [76].

\section{Scope of Review}

The perennial bamboo plant is a rich source of lignocellulosic biomass (such as cellulose, lignin, and pentosan) with a huge potential as a resource that can overcome the current challenges being faced in the use of lignocellulosic biomass as structural materials, in scalable and affordable biofuels production, in bioderivable chemicals and materials production, and as biobased power for energy security, and for mitigating deforestation, improving carbon sequestration, and enhancing the oxygenation of the environment. Furthermore, bamboo cultivation offers positive economic impacts to local economies. In this review, we explore the nexus between engineering-fuel-and-material science to demonstrate that the bamboo plant presents enormous opportunities for technologists, scientists, economists, environmentalists, governments, and engineers. In addition, we highlight the current state-of-the-art bamboo-based green technologies and the challenges restricting the further advancement of such technologies, and we provide recommendations for the direction of future bamboo-based research. 


\section{Background}

Descriptions of the historical uses/applications and other associated benefits of bamboo plants date back centuries. For example, in 400 BC in China, pipes were made from bamboo culm, which was then wrapped in waxed clothes and used in the transportation of natural gas. In another instance, derrick-like structures/scaffolds and winding gears constructed from bamboo were employed in drilling technology in China, in ca. 347 AD [25,77]. It has also been claimed that, in Japanese ancient tradition and culture, bamboo-based materials and implements were used for record-keeping, performing calculations, household accounting, and the making of toys, such as the "bamboo dragon fly" and "bamboo-horse", with the former reported as dating as far back as 400 BC [78]. It is on record that, during a famine period in Orissa (now known as Odisha), India, in 1812 , the seeds of the bamboo plant were cooked and eaten as rice, thereby sustaining thousands of people [79]. Furthermore, it has been reported that the young shoots of several bamboos are eaten, and the seeds of one are made both into a fermented drink and into bread by people living in Himalayan regions [80]. Elsewhere, it is claimed that bamboo materials were employed in the fabrication of one of the earliest light bulbs made by Thomas Edison [81]. Moreover, local belief in Japan has it that, in the event of an earthquake, it is better to run into a bamboo grove for safety [82]. Furthermore, the work of Wang [83] has suggested that bamboo plantations played a significant role in resisting the flow of landslides by shortening the possible sliding distance of the loose earth and debris. In addition, several parts of bamboo plants, including their roots, shoots, and culms, have been used in medicinal applications for thousands of years. For example, Chyawanprash, a well-known Indian health tonic prepared from bamboo, has been noted for its anti-stress and anti-ageing properties [84], and bamboo leaves have also found use in traditional Chinese medicines, such as in the preparation of lotions for particular eye conditions [85]. The report of Freeman-Mitford in 1896, in which he referred to the bamboo as a servant-of-all-work [79], noted that certain bamboo species can grow as high as 40-50 feet in height. Freeman-Mitford's account described the successful cultivation of bamboo plantations in Europe (e.g., France) by the transplantation of selected species from India and Africa (e.g., Algeria), thus enhancing the resilience of the bamboo plant to adapt and flourish anywhere irrespective of the climatic conditions. In 1945, following 12 years of extensive studies in Africa, Wimbush [86] published his work on African alpine bamboos (Arundinaria alpina, K. Schum). In this work, he reported that these bamboos grew to an impressive height of 45-50 feet on average and held an average of $4000-7000$ culms per plant. The report also presented evidence for the average life cycle of these African bamboos being around 40 years, with the life of a single culm ranging from 12 to 14 years, or 8-9 years after clear-cutting of the culms, or 7-8 years when about $10 \%$ of the old culms are left standing at the time of cutting (harvesting), thereby demonstrating the suppleness of this plant.

Bamboos are grasses belonging to the taxonomic family known as Poaceae/Andropogoneae (subfamily Bambusoideae), which consists of more than 1000 species and over 100 genera. Most species of bamboos are known to be fast-growing, with a maturity age between 3 and 5 years. Some bamboos may be a few centimeters tall on maturity (dwarf bamboos), whereas others can reach heights of over 40 feet. These grasses are indigenous to all continents, with the exception of Europe and Antarctica [87]. It has been noted that despite the fact that bamboos are used for various applications by over 2 billion people, it remains a neglected bioresource that could contribute substantially to achieving the UN's sustainable development goals [88]. The anatomical construction of the cell walls of bamboos (Figure 3) and root structural morphology, demonstrate that they are woody giant herbages that can replace timber, improve soil compactness, mitigate deforestation and desertification $[87,89,90]$. Like all woody plants, bamboo stores carbonaceous materials in the forms of cellulose, hemicellulose, tannins, fats, proteins, pigments, pectin, and lignin, with the lignocellulosic biomass components constituting more than $90 \%$ of the total dry mass [91,92]. It has been reported that the yellowness observed in bamboo is caused by the presence of lignin, and no amount of treatment can remove the lignin content present in 
bamboo fibers completely. Moreover, the characteristics of the fibers of bamboo plants, after extraction and treatment, are also dependent on the non-cellulosic components it contains. In contrast to the sandwich-like structure of other woody materials, bamboo fibers are almost axially oriented along the walls of the fibers, thereby maximizing its longitudinal elastic modulus and possessing alternating broad and narrow polymellate structures in the tissue and cell wall of the plant. These characteristics are contributing factors to the high buckling resistance of the bamboo plant $[93,94]$. Nevertheless, fundamental to understanding, harnessing, and optimizing the structural characteristics of bamboos relies on the comprehensive knowledge of their physiological and anatomical properties [89,95]. Li et al. [95] pointed out that the distinct structure and distribution of biomass components in bamboos is key to their utilization and valorization. This review does not cover this subject in greater depth; however, the reader is referred to other texts that have extensively discussed the subject [96-112].

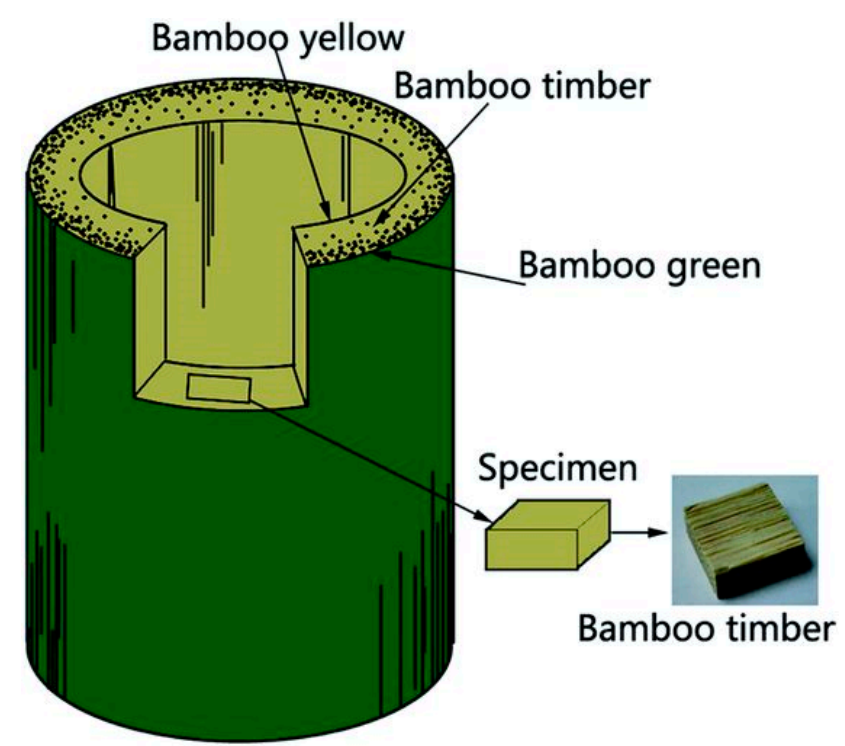

Figure 3. A cut-out section showing the bamboo stem. Reprinted from ref. [103].

\section{Bamboo in Textiles}

The versatility of bamboo-based textiles affords the opportunity for sustainable development. Indeed, bamboo fibers have been used for decades in the production of textile materials. For example, in 1864, Philip Lichtenstadt patented the technology for the fabrication of cloths, mats, and/or pulp for paper from bamboo [104]. Bamboo fibers, shown in Figure 4 , and other natural fibers such as jute, flax, and hemp, are primarily lignocellulosic and are $100 \%$ biodegradable, irrespective of whether they are regenerated (e.g., bamboo viscose) or mechanically and/or biologically extracted [105,106], thereby reducing their environmental impact as pollutants and contaminants. Hence, bamboo-based textiles present an advantage compared to fossil-based textiles such as polyester, acrylics, nylons, and polypropylene, which have been noted as contributing to microplastic pollution in the environment $[107,108]$.

Almost every part of the bamboo plant can be applied to the production of fibers and natural dyes. It has been argued that fibers obtained from these plants demonstrate outstanding characteristics, such as excellent wicking capabilities (exceeding those of cotton fibers), and antimicrobial and anti-odor properties, with these characteristics retained even after multiple wash cycles. In addition, the high carbon content of bamboo fibers promotes enhanced porosity, leading to fabrics with a higher surface area, which is advantageous for the adhesion of organic molecules $[109,110]$. However, the antimicrobial properties associated with bamboo fibers are severely depleted when these fibers undergo the regenerative processes widely employed in industry [111]. This was established as part of the response 
to a previous study by Hardin et al. [112], which claimed that the inherent antimicrobial properties of bamboo fibers were exaggerated.

Rathod et al. [113] analyzed the physical characteristics of both pure bamboo and bamboo-cotton (50:50) blended fabrics, demonstrating that bamboo fabric exhibited improved tensile strength, higher elongation values, and superior tearing resistance in comparison to the bamboo-cotton (50:50) blend, thereby concluding that the bamboo fabric demonstrated better performance than the blended fabric. This position is supported by the report of Iqbal et al. [114], who established that the properties of bamboo strips, including the tensile, flexural, and compressive strengths, were superior in comparison with those of wood and other bioderived fibers. In addition, the bamboo fibers demonstrated better impact and thermal properties [114]. Patent documents reveal proposed technologies intending to exploit the exceptional thermal properties of bamboo fibers to fabricate clothing materials that provide effective insulation in the winter while being breathable in the summer [115]. Related work has justified the need for developing winter apparel using a blend of $100 \%$ regenerated bamboo fabric and $100 \%$ cotton. The study concluded that, for 60 tex ring-spun yarn in a bamboo-cotton fabric blend (50:50), the contributory air permeability of the regenerated bamboo fabric had a positive impact on the breathability of the blended textile. Moreover, the plain-woven bamboo-cotton fabric in a 50:50 ratio demonstrated improved thermal conductivity and heat retention properties [116]. This study corroborated the work of Basit et al. [117].

Furthermore, it has been shown that there is no remarkable distinction between cellulose acetate derived from traditional wood pulp and that derived from bamboo plants, indicating that bamboo has the potential to replace wood pulp for cellulose-derived fibrous materials, thereby mitigating deforestation and enabling forest sustainability [118]. Another report has evidenced a clean production method for bamboo fibers. The proposed method involves an efficient, continuous production line using purely biological treatment processes capable of producing bamboo textiles of high quality. Consequently, this method produces minimal pollution and has a limited or no chemical footprint, with the added advantage of energy conservation and being environmentally friendly [119], thus presenting an opportunity for the production of sustainable and eco-friendly textiles.

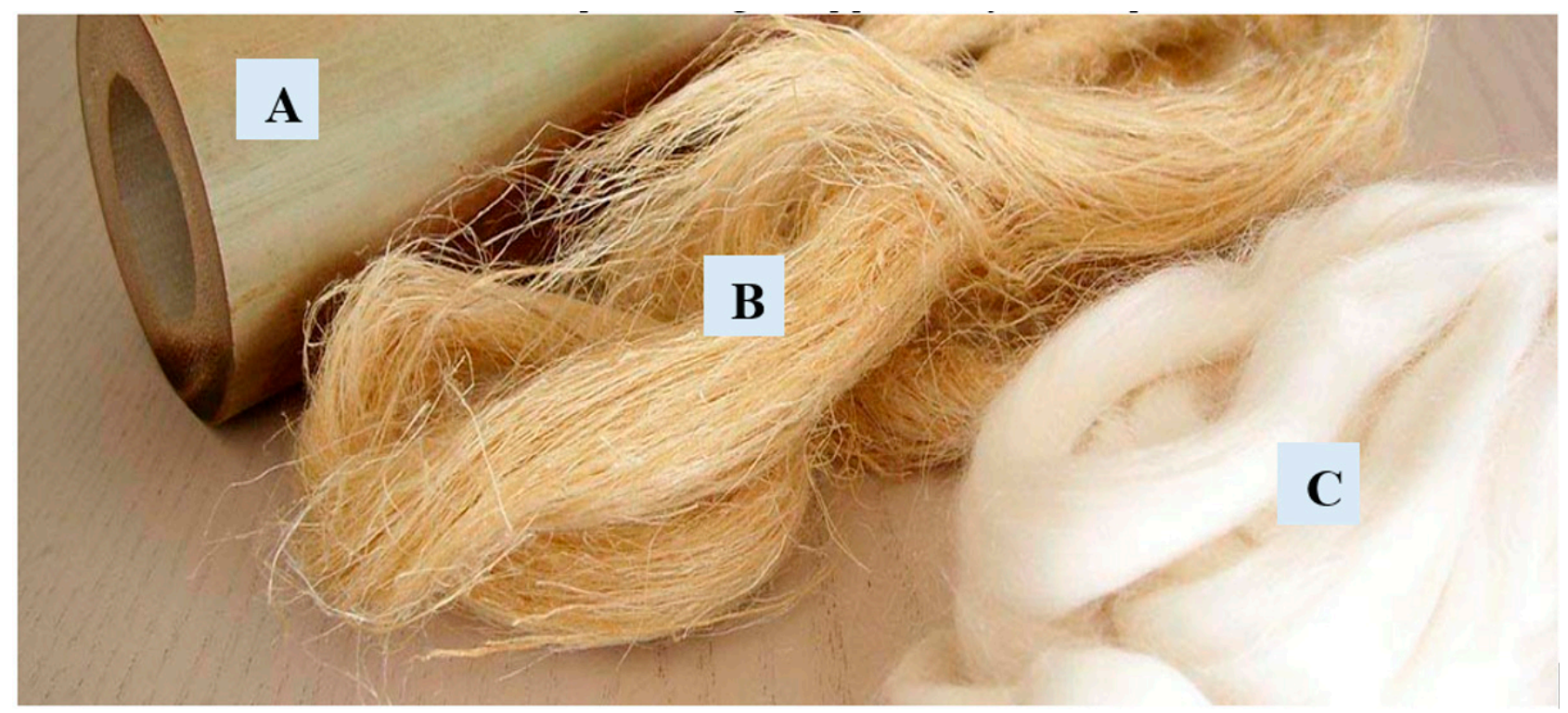

Figure 4. Bamboo fibers. (A) bamboo culm, (B) bast fibers extracted from bamboo, (C) bamboo yarn (viscose bamboo). Adapted from ref. [120].

Kaur et al. [109] demonstrated a two-stage methodology for the treatment of coarse and stiff bamboo fibers to enhance their fibrillation and spinnability for use in the textile industry. Their study claims that their treatment methodology produced more lightweight 
bamboo fibers with reduced lignin content, in addition to an acceptable level of whiteness, impressive tensile strength and fibrillation, and sufficient fiber length. This suggests that, to obtain the optimal properties offered by bamboo fibers, an improved method for fiber treatment is essential for maintaining the ideal lignin content while ensuring that the fibers retain their natural mien. A recent study by Ławińska et al. [121] investigated the application of bamboo textiles in the fabrication of children's footwear. Their findings are summarized as follows: (i) it is feasible to weave or knit fabrics from bamboo fibers suited for children's footwear; (ii) particular cases demonstrated that bamboo fibers exhibited improved mechanical properties when compared to traditional cotton fibers; and (iii) bamboo fibers demonstrated improved hygienic characteristics relative to the standard requirements for the production of children's footwear. Moreover, it has been reported that the United States Office of Naval Research, in partnership with Research Triangle Park, North Carolina, developed a bandage (Stasilon ${ }^{\mathrm{TM}}$ | FR), that can effectively stop the bleeding of wounds inflicted during combat. This novel bandage was developed from a combination of medical grade continuous-glass-fiber and bamboo textile [122].

Elsewhere, Jhatial et al. [123] demonstrated that it is feasible to affix silica nanoparticles and titania nanoparticles on bamboo cellulose fabrics by the sol-gel (dip-pad-dry-pad-cure) method using citric acid as a crosslinking agent. The optimum water contact angles exhibited by this material were $\sim 127^{\circ}$ and $\sim 116^{\circ}$ before and after washing, respectively, indicating that this material has impressive hydrophobicity, low wettability, and can retain its impressive water repellence for up to five industrial washes. It also retained its original air permeability, fabric feel, and good soil release potentials, the inherent fabric comfort was not compromised, and it exhibited effective UV resistance, reducing transmittance from $49 \%$ to $6 \%$ [123]. The findings of another recent study, which analyzed footwear materials based on bamboo fabrics and cotton fabrics, provided the following conclusions: bamboo fabrics are a suitable replacement for cotton materials in footwear fabrication, with bamboo outperforming cotton in several key parameters, namely hygiene and/or mechanical properties, such as breathability [124]. Compared to non-biodegradable fossilderived fibers (e.g., nylon, polyesters, polyethylene terephthalate [PET]), which have been shown to contribute substantially to microplastic pollution $[108,125,126]$, it is safe to posit that natural fibers such as those derived from bamboo offer the scientific community a wealth of possibilities.

\section{Bamboo in Composites and Construction}

The quest to mitigate environmental degradation while seeking ways to fabricate and/or develop composite materials that are both cost-effective and eco-friendly has been the impelling cause behind the scientific community's search for viable alternatives to traditional materials currently in use. Recent years have witnessed the growth in the fabrication of composite materials from renewable resources, such as bamboo-reinforced materials, with these materials gradually gaining recognition in response to the growing exigency for environmental sustainability and recyclable materials. [93]. This line of thought is supported by the work of Okubo et al. [127], who showed that bamboo fibers exhibit commensurate strength to conventional fiber-glass polymer composites. Their work demonstrated further that the most effective process in the extraction of bamboo fibers for use in polymer reinforced composite materials is the steam explosion technique. Alternatively, another report describes an innovative approach involving fast pyrolysis and short processing times for the cleaner conversion of bamboo into carbon fibers. These fibers were shown to possess interesting physicochemical and capacitive properties (possessing high carbon contents resulted in improved capacitive properties of the fibers), in addition to enhanced carbon fixation and surface area. Moreover, these fibers demonstrated potential for use in electrode production for energy storage [128].

Moreover, Wang et al. [129] indicated that, in addition to studies considering the macroscale properties of bamboo fiber-reinforced structures, in order to optimize the properties of bamboo fibers as reinforcement agents in composite materials, there is a need for more 
comprehensive analyses of the micro- and nano- structural properties of bamboo fibers. This is because bamboo fibers consist of a complicated multi-hierarchical configuration that includes macro-, micro-, and nanofiber systems, with each of these demonstrating specific characteristics and properties [130]. Typically, failures in fiber-reinforced composite materials can, among other factors (e.g., treatment processes), be attributed to the fiber orientation in the matrix system, i.e., fibers aligned parallel $\left(0^{\circ}\right.$ orientation) to the applied tensile force results in better resistance to failure and breakage than fibers aligned above $0^{\circ}$ to the applied force [131]. Hence, for fiber-reinforced matrices such as bamboo fiberreinforced epoxy resin, the strength of the composite system was observed to increase when the orientation of the fibers shifted from $90^{\circ}$ towards $0^{\circ}$ [132]. Because bamboo fibers are characterized by a complex multi-hierarchical structure of macro-, micro-, and nanoscale fibers, the variability of the fundamental fiber diameters has a significant effect on the bamboo fiber strength. For example, at the micro-scale level, it was observed that with an increase in the mean diameter of the fibers from 196.6 to $584.3 \mu \mathrm{m}$, the average strength of the bamboo fibers decreased from 568 to $483 \mathrm{Mpa}$; because inter-fiber diameter variation is key to the fibers' tensile strength, it is paramount that technologists, scientists, and material engineers have a proper understanding of this statistical strength distribution and consider it when modelling and fabricating polymer composites employing bamboo fibers as a reinforcement agent [129]. In addition, the tensile behavior of chemical treatments for bamboo epoxy composites has been investigated [132]. This study highlighted the optimal treatment required to enhance the surface adhesion chemistry of bamboo fibers within an epoxy matrix. In summary, the results showed that an alkali treatment of the bamboo fibers improved the bonding chemistry between the fibers and the polymer matrix. According to the subsequent statistical analysis, it was evidenced that variables (such as concentration of the chemical solution, duration soaking, and drying time of fibers) and their interaction parameters such as alkali concentration, soaking, and drying time were significant in this improved bonding. The work concluded that an optimal tensile strength of 335.84 MPa was obtained from the composite system after soaking (in 3\% wt. of $\mathrm{NaOH}$ before incorporation into the epoxy matrix) and drying the bamboo fibers for $9 \mathrm{~h}$ of soaking and $55 \mathrm{~h}$ of drying. Any deviation in these optimal values impacted negatively on the tensile strength of the composite material [132]. The impact of moisture on the mechanical properties of bamboo fiber-reinforced composites has been reported by Depuydt et al. [133]. The static and hygroscopic cyclic conditioning was evaluated, and it was deduced from the study that only a minute decrease in Young's modulus was observed under the static conditioning of bamboo fiber-reinforced composites, representing a remarkable departure from what was observed in other natural fiber-reinforced composites, e.g., flax-reinforced polymer composites [133].

A recent report from France narrated how a consortium of various industry stakeholders, companies, and research laboratories are pooling their expertise in order to develop a bioresourced composite material using bamboo fibers. The report stated that following the possibility of a review of the European Registration, Evaluation, Authorisation and Restriction of Chemicals regulation concerning traditional polymer composites currently employed in the aerospace industry, such as glass/phenolic composites, there is an urgent need for ecofriendly replacement materials that are equally effective. Therefore, this French consortium has proposed a new composite material known as BAMCO (Bamboo long-fibers-reinforced biobased Matrix Composite). The aim is to reduce the detrimental environmental footprint of the aircraft manufacturing processes and for the delivery of associated benefits beyond the industry. As this new composite material intends to reduce the overall weight of aircraft, it should lead to reduced fuel consumption and operational costs for the aviation industry, while also contributing favorable thermal and mechanical properties in terms of impact/vibration absorption. The concept for this biocomposite has undergone both laboratory and industrialscale validation by French aviation authorities [134].

Elsewhere, Mofidi et al. [135] reported on the performance of innovative bamboo composite materials (shown in Figure 5), which they claimed exhibited compressive strengths 
of 30 and $76 \mathrm{MPa}$, respectively, highlighting the possibilities of such composites for use as construction materials. Citing their motivation from the fact that certain bamboo species employed in construction have exhibited tensile strengths ranging between 400 and $1000 \mathrm{MPa}$, they opined that, with further elucidation, bamboos are a viable alternative to timber and possibly outperform construction steel with respect to their weight-to-strength ratios. They deduced that engineered bamboo composite materials made of small diameter bamboo culms have the potential to replace other carbon-intensive traditional materials, such as concrete, steel, and aluminum, without any attendant negative impact on forest reserves. Moreover, the study emphasized the advantages presented by these fabricated materials, including proportionate strength, better ductility, and improved energy absorbency relative to non-composite bamboo materials [135]. Another study investigated the possibility of developing a low-cost and benign composite material that can be applied in the blades of wind turbines. This report claims that hybridization of natural fibers such as jute and bamboo in a polyester matrix at a ratio of 10:20:70, respectively, yielded a material with an impressive tensile strength of $72.03 \mathrm{MPa}$. Notwithstanding this result, it was inferred that bamboo-polyester matrix in a ratio of 30:70 yielded better flexural strength (133.9 $\mathrm{MPa}$ ). These results demonstrate that hybridized natural fiber materials have the potential to optimize the strength of composites in particular applications, such as wind turbines [136].

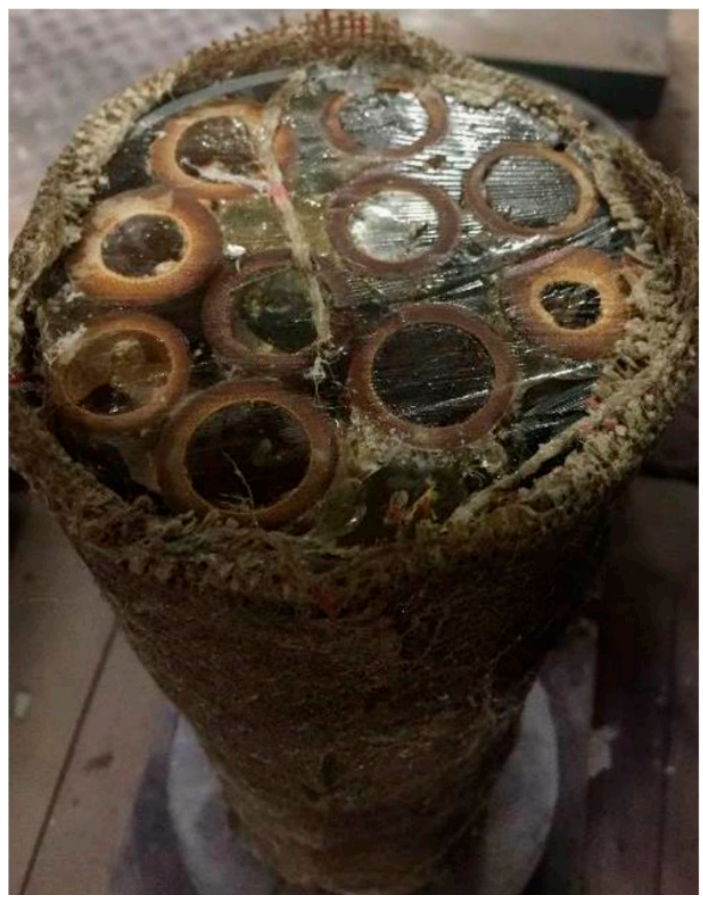

Figure 5. Innovative bamboo composite engineered by Mofidi et al. reprinted from ref. [135].

In an attempt to revive the days when bicycles dominated the cities of China, a project founded by David Chin-Fei Wang has initiated advocacy for the construction of bamboo bicycles for sustainable mobility. Since 2017, this project, known as bamboo bicycle Beijing (BBB), has gained steadily increasing recognition of local populations. Coupled with reports that more than $15 \%$ of recorded deaths in China result from air pollution, accompanying an associated reduction in the average life expectancy by more than four years, and with the "Greenpeace initiative" championing the cause for Beijing to be ranked among the healthiest cities in the world, the BBB project is a welcome development. This project further demonstrates that bamboo as a construction material can displace metal-based materials in bicycle manufacturing in terms of its relative lightness, strength, inherent capability to withstand shock, and ability to dampen vibrations resulting from use [137,138].

A report by researchers based at the University of Cambridge in the United Kingdom stated that the mapping of heat-flow processes across biological materials, such as 
bamboo, using advanced scanning thermal microscopy, provided new insights into how the variations in thermal conductivity throughout the structure of bamboo can be utilized to develop improved energy-efficient and fire-safe buildings. The thermal properties of materials, such as their thermal conductivities, play a significant role in the selection of materials for building/construction purposes because they determine the rate at which temperature is distributed throughout a building's structure, and affect the spread and control of fire [139]. The consumption of energy in buildings has been reported to account for more than $30 \%$ of global energy depletion and to be a significant contributor to $\mathrm{CO}_{2}$ emissions. Hence, the need for energy-efficient materials for sustainable buildings cannot be overemphasized [140]. A team of architects and engineers constructed an ambitious bamboo structure that serves as a sizeable sports hall. The structure is reported as promoting natural ventilation and possessing sufficient robustness to withstand severe weather while also having a zero-carbon footprint [141].

A symposium consisting of multidisciplinary experts drawn from over ten countries and territories, including those working in academia, construction, architecture, civil society groups, etc., reached a consensus to raise awareness on the critical role bamboo holds, not only in the provision of safe and affordable housing, but also as an industry leader for a global green movement. The meeting was organized jointly by the University of Pittsburgh, Coventry University, and the International Network for Bamboo and Rattan (INBAR) [142,143], and is hoped to expand the opportunities of bamboo usage in diverse applications for sustainable development. Elsewhere, a collaboration between the University of Queensland, Australia, and Moso ${ }^{\mathrm{TM}}$ bamboo demonstrated that during fire-testing, bamboo produces a protective outer layer of char, which protects its inner layers from direct fire exposure, an indication that bamboo exhibits relatively good fire resistance and can be used for construction [144]. For example, terminal 4 at the Adolfo Suárez MadridBarajas International Airport is composed entirely of curved bamboo ceilings; completed in 2005, this magnificent structure is one of the reference projects championing bamboo as a construction material [145].

The possibility of replacing steel with bamboo strips in concrete reinforcement has been proposed, and is plausible because of the possibilities of the high rate of biomass renewability and sustainability through a well-managed bamboo plantation [146]. The characteristic strength of bamboo in the dry mass ranges between 30 and $50 \mathrm{Mpa}$, respectively, and in some instances, can reach $250 \mathrm{Mpa}$, commensurate to about $20 \%$ of the tensile strength of grade- 60 steel, and a modulus of elasticity of $\sim 20 \mathrm{GPa}$, proportionate to $10 \%$ of the grade- 60 steel. A clear indication that, the assumptions that bamboo is comparable to steel without any form of material modifications are not valid [146]. Nevertheless, it was evidenced that among the challenges encountered in the utilization of bamboo as reinforcement in concrete was the failure of tensile samples of the bamboo-reinforced concrete without warning. This highlighted that the weakness of the nodes is more pronounced than the weakness of the internodes when both are subjected to the same tensile loads. Moreover, the variance in both the tensile and bond strengths of bamboo posed further challenges for realizing its reinforcement potential. However, various methodologies employed to improve the bamboo-concrete reinforcement were observed to be beneficial. For example, wired reinforcement showed a strength increase of $17 \%$, and strips with corrugations showed a strength increase of more than $70 \%$. Cracking of the bamboo-reinforced concrete beams became noticeable within a load range of $12-14 \mathrm{kN}$ [147]. A related study claimed that using bamboo-reinforced-epoxy-composites (BRECs) as an alternative for steel-rods in concrete-reinforced beams improved the flexural strength of the concrete. The study reported that the load-bearing capacity of the beam with BRECs without preloading was increased by $21.2 \%$, increasing to $37 \%$ for BRECs with $40 \%$ preloading and $39.3 \%$ for the beam with BRECs preloaded at $60 \%$. The study concluded that using embedded BRECs represents an effective technique to improve the flexural strength of reinforced concrete [148]. 


\section{Bamboo as a Sustainable Resource for Cellulose, Hemicellulose, and Lignin}

Iroegbu et al. [34] noted that the complex hetero-matrix constituents of lignocellulosic biomass comprising primarily of cellulose, lignin, and hemicellulose affords an array of possible derivative chemicals and fuels. It was also suggested that if efforts (including research, funding, and support) commensurate to those that have sustained fossil-based chemistry were redirected into biobased-chemistry, it would significantly accelerate the resolution of current sustainability challenges [34]. Moreover, as the approximate chemical constituents of bamboos are comparable to those of traditional woods, with the exception of bamboos' substantial alkaline extracts, ash, and silica components [149], bamboos offer a renewable and sustainable alternative for the augmentation of derivable lignocellulosic biomass materials, such as cellulose, hemicellulose, lignin, and other extractable constituents [90]. Although these components vary due to the age of bamboo plants, the range of variation is estimated at between $1.4 \%$ and $3.8 \%$. In addition, Table 2 lists the average values for holocellulose (cellulose, hemicellulose) and lignin as $40-48 \%$ and $25.8-30 \%$, respectively, corresponding approximately to the averages reported for softwoods and hardwoods, respectively. Therefore, the lignocellulosic composition of bamboo represents a useful feedstock not only for pulp production, but also for industrial processes that require lignocellulosic biomass for conversion into fuels, chemicals, and various biobased products [88].

Table 2. Selected studies show the percentages (\%) of holocellulose (cellulose, hemicellulose) and lignin in the composition of the bamboo plant.

\begin{tabular}{|c|c|c|}
\hline $\begin{array}{c}\text { Bamboo Species } \\
\text { Sampled }\end{array}$ & Cellulose, Hemicellulose and Lignin Contents (\%) & Ref. \\
\hline Unspecified & Cellulose $(73.8 \%)$, hemicellulose $(12.5 \%)$, lignin $(10.2 \%)$ & [150] \\
\hline $\begin{array}{l}\text { Phyllostachys (nigra, } \\
\text { bambusoides, bissetii) }\end{array}$ & Cellulose (47\%), hemicellulose (23\%), lignin (28\%) & [88] \\
\hline Phyllostachys edulis & Cellulose (43\%), hemicellulose (15\%), lignin (26\%) & [151] \\
\hline $\begin{array}{c}\text { Dendrocalamus } \\
\text { giganteus }\end{array}$ & Cellulose (47\%), hemicellulose (16\%), lignin (18\%) & [152] \\
\hline Unspecified & Cellulose (44\%), hemicellulose (30\%), lignin (26\%) & [153] \\
\hline Phyllostachys edulis & Cellulose (46\%), hemicellulose (23\%), lignin (26\%) & [154] \\
\hline Dendrocalamus asper & Cellulose (41\%), hemicellulose (27\%), lignin (27\%) & [155] \\
\hline $\begin{array}{l}\text { Phyllostachys (dulcis, } \\
\text { viridiglaucescens) }\end{array}$ & Cellulose $(38.4 \%)$, hemicellulose $(20.5 \%)$, lignin $(20.8 \%)$ & [156] \\
\hline $\begin{array}{c}\text { Phyllostachys } \\
\text { heterocycla }\end{array}$ & Cellulose (37\%), hemicellulose (22\%), lignin (24\%) & [157] \\
\hline
\end{tabular}

\subsection{Cellulose}

Arguably, this unbranched polymeric material, with the well-known molecular structure illustrated in Figure 6, is the most significant component within the plant cell structure. A naturally occurring polymer with almost boundless application potential in the field of chemical sciences, cellulose has, over the years, gained increasing prominence in multidisciplinary research studies and product development. In addition to its unlimited availability, cellulose is characterized by its highly functional groups, hydrophilicity, chirality, biodegradability, versatility in chemical modifications, and its capability to form numerous semi-crystalline fibers morphologies, thus making it a cornerstone of many natural structures $[158,159]$. 


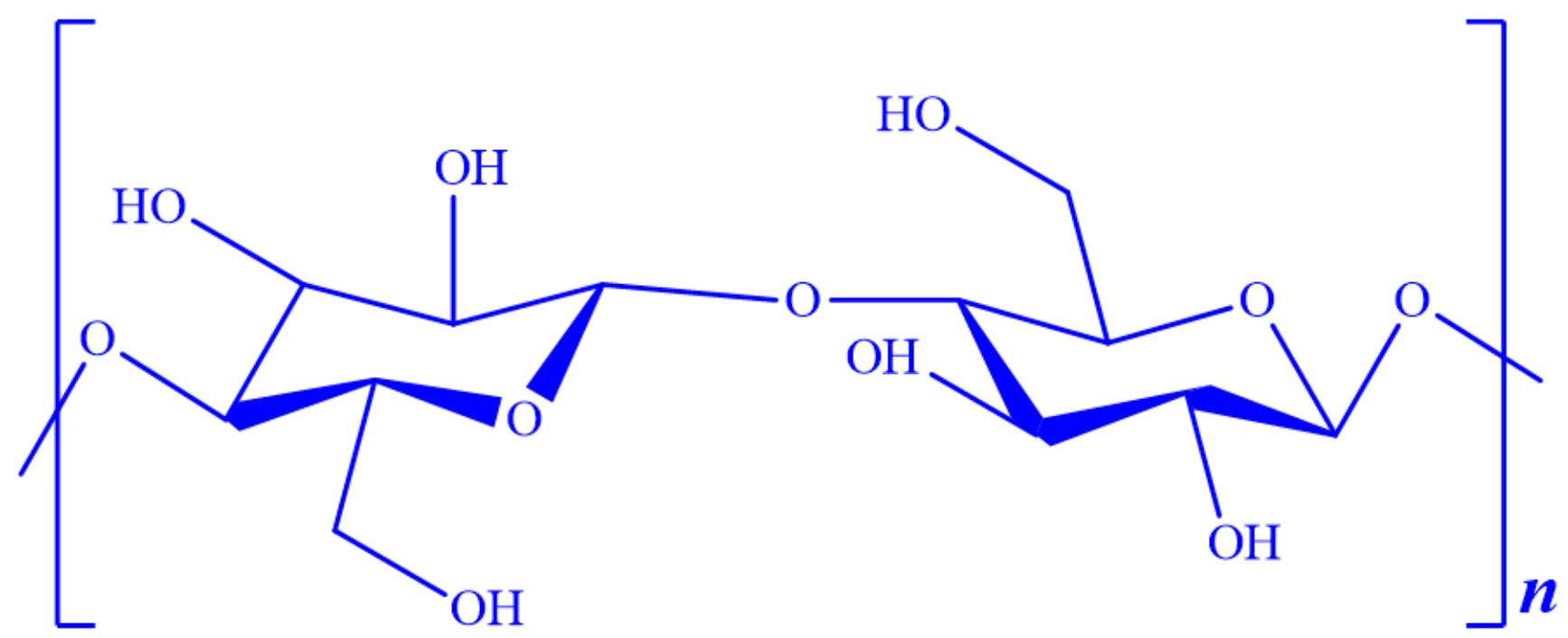

Figure 6. Molecular structure of cellulose (where $n=$ degree of polymerization). Credit: Authors.

The potential applications of cellulose have been known for over a century. Among the earliest demonstrations of cellulose as a versatile chemical compound that can be transmuted into various fuels, materials, and chemicals is patent documentation dating to 1894, which proposed the possibility for producing a water-soluble plastic material using cellulose, a caustic alkali, and carbon disulfide [160]. Then, in 1900, Augustus G. Winter [161] demonstrated the possibility of fireproofing cellulose material to enable it to withstand a temperature of approximately $1000^{\circ} \mathrm{C}$. Over the years, cellulose has found increasing application in the production of biofuels (e.g., ethanol), nanomaterials (e.g., for water remediation), particle board production, membranes for water desalination, adhesives, packaging, printing, coatings, glucose (e.g., for human energy source, sweetener, polyols, fructose, polydextrose, etc.), paper, cellulose esters and composites, gelling agents, cellulose ethers for drilling technologies and building materials, cosmetics, pharmaceuticals, and many more $[63,81,159,162-166]$.

\subsection{Hemicellulose}

A branched, amorphous, and complex polymeric material (see Figure 7), which is a rich source for pentosan (xylan or polypentose), hemicellulose is a feedstock for the production of chemicals such as furans. It can be hydrolyzed with ease by employing dilute acids and/or bases. In addition, hemicellulose is biodegradable and, by employing enzymes, selected bacteria and/or fungi can be broken down to form smaller sugar systems $[30,55]$.

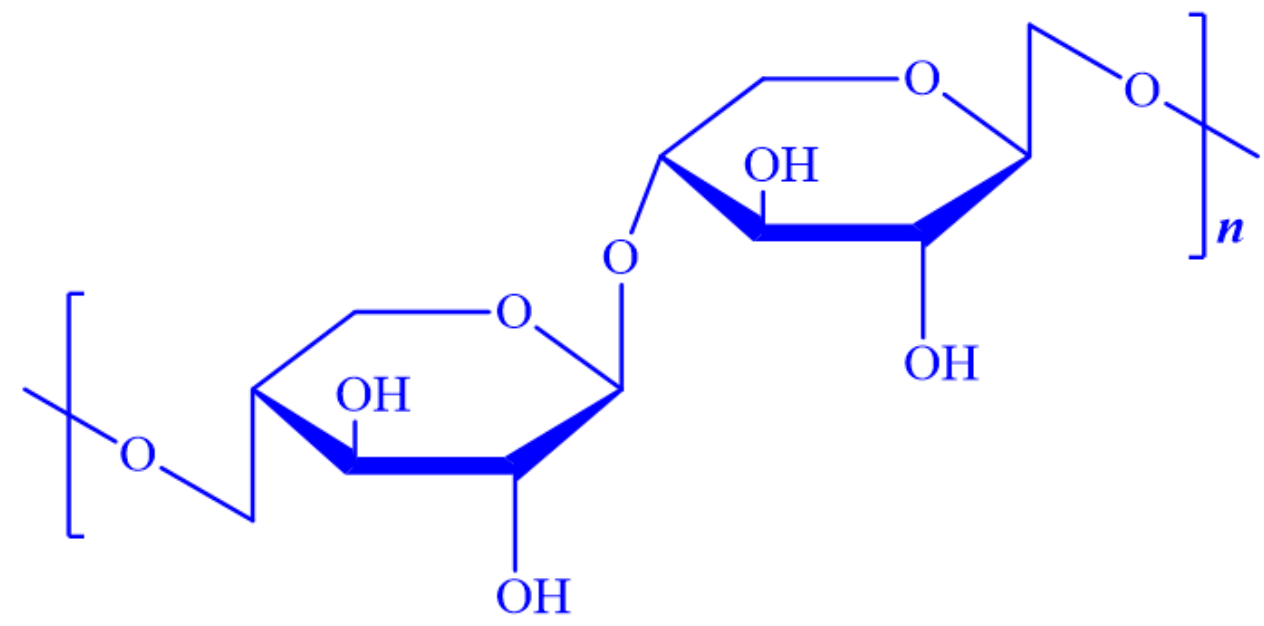

Figure 7. Molecular structure of pentosan (where $n=$ degree of polymerization). Credit: Authors. 
Among the fuels, materials, and chemicals derived from hemicelluloses, ethanol, xylitol, and 2,3-butanediol are perhaps the best known. In addition, hemicellulose has found use in medical and pharmaceutical applications, and the production of furfural (which can be used as an automobile fuel or used for the production of diesel, jet fuel, etc.), furfuryl alcohol (used for producing kerosene, rigid foams, molecular sieves for water desalination, antiknock additive, composites, diesel, etc.), hydroxymethyl furfural (a very important building block in organic synthesis), levulinic acid, adipic acid, caprolactone, caprolactam, 1,6-hexanediol, and 2,5-furandicarboxylic acid, which is a versatile and industrially important chemical compound that finds application in the production of ropes, textiles, coatings, gums, footwear, and polyethylene furanoate (PEF) $[34,55,59,166]$.

\subsection{Lignin}

A 2019 report by the World Economic Forum posited that lignin will rank amongst the top emerging technologies of tomorrow and is predicted to play a momentous role in the quest and progress of the circular economy and in the production of sustainable chemicals, materials, and fuels in the near future [74]. Lignin is not only an abundant aromatic polymer, but it is also sustainable and demonstrates the potential to replace fossilderived aromatics and products due to its unrivalled functionality (shown in Figure 8). As a consequence, the chemical modification of lignin offers numerous possibilities in terms of creating targeted value-added products. In addition to its polymeric network structure, which can be an added advantage for enhancing its composite applications, lignin can also be depolymerized, transformed, or even copolymerized with other polymeric systems, such as phenol-formaldehyde, to obtain materials with unique properties for industrial and domestic applications [167]. Lignin finds application in a range of industries and products, including construction, electronics, composites, adhesives, plastics, cement additives, antioxidants, carbon nanotubes, sizing agents, lubricants, cresols, catechols, resorcinols, quinones, crosslinking agents, vanillin, guaiacols, binders and/or emulsifiers, soil remediation agents, dispersants, complexing agents for paints and coatings, dyes, and oil drilling muds $[72,73,75,77,167-178]$.

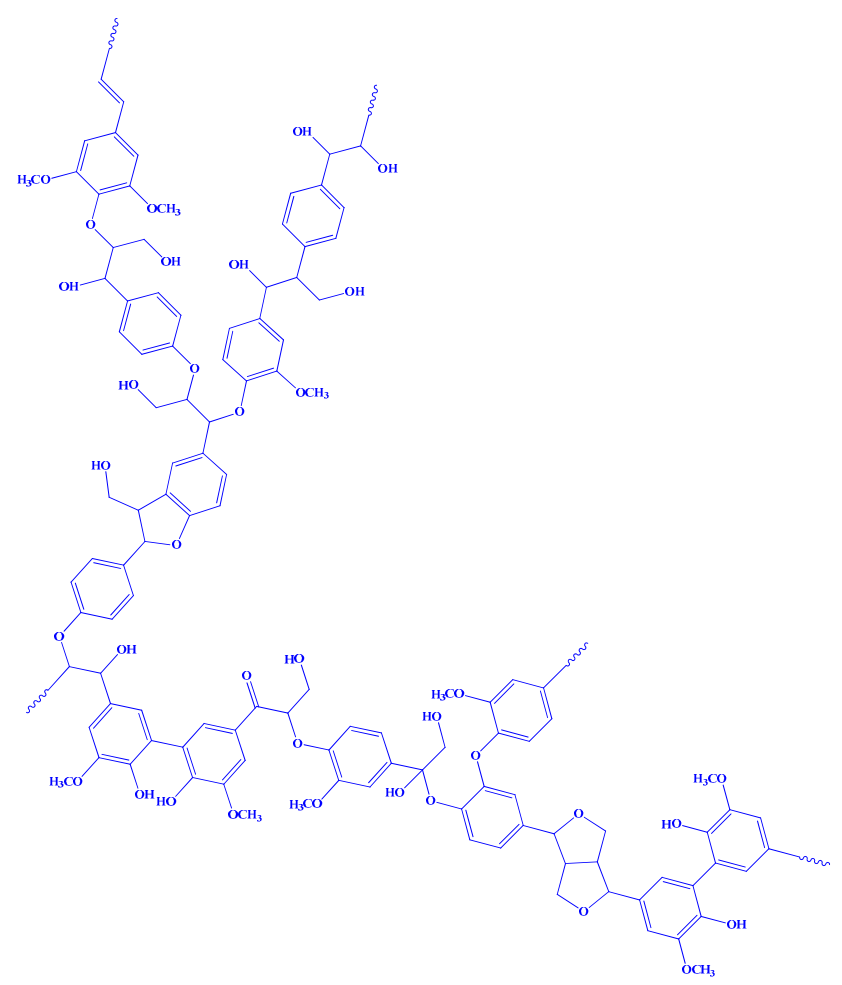

Figure 8. Molecular structure of lignin, adapted from [167]. 


\section{Bamboo as a Resource for Functional Biochar and Charcoal}

As a potential material for soil remediation and management, biochar has been studied for over 150 years. For instance, in 1851, the positive effect of charcoal dust in quickening and increasing vegetation yield was observed by Trimble [171]. Then, in 1915, Retan [172] published a report on the positive results that soil impregnation with charcoal had on nursery seedlings. Since the 1980s, research into biochar optimization in various horticultural activities has intensified [173]. The potential of bamboo for biochar production is recognized as being uncomplicated, low-cost, and environmentally benign. Coupled with the fact that bamboos are a fast-growing source of vegetation, they hold a huge potential for carbon sequestration through their biomass pyrolysis to produce biochar for soil remediation and environmental management [174]. Furthermore, it has been demonstrated that bamboo biochar is an efficient carbonaceous material for the mitigation of organic pollutants. One study argued that impregnating soils with biochar from bamboo abated the leaching of pentachlorophenol (PCP) into the soil by decreasing the cumulative leach-loss content by $42 \%$, while also reducing the PCP concentrations by $56 \%$ and $65 \%$ in methanol and distilled water, respectively. These results indicate that bamboo biochar can protect groundwater from being contaminated by leachates [175].

A study to investigate the role of bamboo biochar in the aerobic composting of poultry manure showed that bamboo char aided the porosity, air permeability, and oxygen supply of the compost. It was also demonstrated that the bamboo biochar helped to reduce greenhouse gases such as $\mathrm{CO}_{2}, \mathrm{CH}_{4}$, and $\mathrm{N}_{2} \mathrm{O}$, in addition to reducing ammonia emissions. For a weight-to-volume ratio of $10 \%$, low-cost bamboo biochar was found to aid organic matter degradation and compost maturity. Together, the outcomes of this study highlight the huge potential that bamboo biochar holds for poultry compost management [176]. A related study considered the effect of bamboo biochar on fungal biota progression during poultry manure compositing, providing evidence that bamboo biochar efficiently activated fungal dynamism throughout the composting process, with an increase in the relative abundance of the fungal biota as the biochar dosage increased [177]. Switching focus to wastewater remediation, antibiotics such as fluoroquinone present an environmental hazard. However, the work of Wang et al. [178] demonstrated the possibility of adsorptive removal of fluoroquinone antibiotics from polluted wastewater systems using bamboo biochar. Their study reported a $99 \%$ efficiency for the bamboo biochar with respect to removing the antibiotic pollutant. However, it was noted that a $\mathrm{pH}$ change from 3 to $10 \mathrm{impacted}$ the adsorption capacity of the biochar. The study reported that the maximum adsorption capacity (45.88 $\left.\pm 0.90 \mathrm{mg} \cdot \mathrm{g}^{-1}\right)$ of the biochar was recorded when the concentration of bamboo biochar exceeded that of fluoroquinone by a factor of 10 .

Bamboo biochar has also been deployed for other important industrial applications, such as in lithium battery manufacturing. For example, Gu et al. [179] showed that porous bamboo biochar, activated using the $\mathrm{KOH}$ /annealing process, was able to create a microporous structure, thereby enhancing the surface area of the biochar for improved electronic conductivity. This activated microporous biochar was used in the encapsulation of elemental sulfur to prepare a microporous bamboo carbon-sulfur (BC-S) nanocomposite, which was employed as the cathode end for lithium batteries. This innovative nanocomposite composition consisted of $50 \mathrm{wt} . \%$ sulfur content and was found to deliver an impressive initial capacity of $1295 \mathrm{~mA} \cdot \mathrm{h} / \mathrm{g}$ at a low discharge rate of $160 \mathrm{~mA} / \mathrm{g}$, while exhibiting high-capacity retention of $550 \mathrm{~mA} \cdot \mathrm{h} / \mathrm{g}$ after 150 cycles at a discharge rate of $800 \mathrm{~mA} / \mathrm{g}$ with an impressive coulombic efficiency ( $\geq 95 \%)$. Hence, it was concluded that the BC-S nanocomposite shows promise as an efficient cathode material for next-generation lithium-sulfur batteries [179]. Similarly, another study demonstrated the fabrication of a sulfonated-polyaniline coated with bamboo-derived biochar, which exhibited exceptional dual conductivity and affinity for polysulfides, for application as a cathode in lithiumsulfur batteries. This cathode, which consisted of $64 \%$ wt. of sulfur, demonstrated an impressive initial discharge capacity of $1484 \mathrm{~mA} \cdot \mathrm{h} / \mathrm{g}$ at $0.1 \mathrm{C}$ and improved cycling stability of $853 \mathrm{~mA} \cdot \mathrm{h} / \mathrm{g}$ after 100 cycles at $0.1 \mathrm{C}$, with a significant rate performance of 810.2, 
682.7 , and $353.0 \mathrm{~mA} \cdot \mathrm{h} / \mathrm{g}$ at 2, 3, and $5 \mathrm{C}$, respectively. Furthermore, the study presented electrochemical impedance spectroscopy and density functional theory calculations that confirmed that this composite cathode possesses extremely high electron and Li-ion conductivities, which are critical in the enhancement of redox reaction kinetics during the long-term cycling of these batteries [180].

Elsewhere, a functionalized bamboo charcoal for the improvement of indoor environmental air quality was reported by Ren et al. [181]. By loading the multifunctional bamboo charcoal with silver-doped titanium dioxide $\left(\mathrm{Ag} / \mathrm{TiO}_{2}\right)$ via a sol-gel process, a composite material was developed that showed remarkable antibacterial efficiency in response to both Escherichia coli and Staphylococcus aureus strains. In short, the results concluded that biobased bamboo charcoal holds the possibility of developing materials with bactericidal and humidity control functions [181]. It has been claimed that because bamboo charcoal possesses a natural hierarchical porous three-dimensional network structure and good electrical conductivity, it can be used to produce anodal terminals for lithium-ion batteries. $\mathrm{Xu}$ et al. [182] demonstrated that by employing a superficial synthetic method in tandem with electrochemical methods, activated bamboo charcoal-supported molybdenum disulfide $\left(\mathrm{MoS}_{2}\right)$ nanoflakes could be developed as an anode material for lithium-ion batteries. In addition to its impressive high-rate capacity of $581 \mathrm{~mA} \cdot \mathrm{h} / \mathrm{g}$ corresponding to a current density of $1600 \mathrm{~mA} / \mathrm{g}$, the optimal $\mathrm{MoS}_{2} /$ bamboo-charcoal material delivered an initial capacity of $1867 \mathrm{~mA} \cdot \mathrm{h} / \mathrm{g}$ at a current density of $200 \mathrm{~mA} / \mathrm{g}$, accompanied by a stable reversible capacity of $672 \mathrm{~mA} \cdot \mathrm{h} / \mathrm{g}$ over 200 cycles. This impressive electrochemical accomplishment of the $\mathrm{MoS}_{2} /$ bamboo charcoal material was attributed to the synergistic effects between the $\mathrm{MoS}_{2}$ and the aforementioned hierarchical porous structure of the bamboo charcoal, which was significant in buffering the volume change and enhancing the conductivity of the hybridized composite material [182]. Bamboo charcoal has also found usage in oral dental care products. For example, it has been pointed out that bamboo charcoal fibers impart freshness, relieve bacteriostatic itching, and help remove atypical mouth odors. Other noted characteristics of bamboo charcoal in oral dental care include teeth whitening and the absorption of dirt from oral cavities, thereby reducing bacterial growth [183].

\section{Sundry Uses of Bamboos}

Bamboo plants are also used in a variety of other capacities, a few of which are discussed in this section. Bamboo has been used to manufacture sustainable and ecofriendly straws as an alternative to the pervasive plastic straws derived from fossil-based hydrocarbons [126]. In addition, bamboo is used to produce household furniture, including ceilings, floors, and staircases [184]. Bamboo also represents a food source for humans and animals, as well as being used in traditional medicine in Asia and India [185].

\section{Economic and Environmental Perspectives}

The Netherlands Ministry of Economic Affairs reported that bamboo plants hold enormous potential for sustainable resources in the quest for a global biobased economy. In addition to presenting itself as a formidable substitute for timber and the subsequent mitigation of deforestation, with research optimization, bamboo can offer an almost inexhaustible resource for biomass and energy security in the future. The report highlighted that bamboo pulp can replace wood pulp for cellulose derived textiles and other cellulose derivatives such as viscose-rayon, cellulose esters, and cellulose ethers. It was further noted that managing bamboo crops requires little or no need for pesticides and/or biocides as it is seldom attacked by pests or diseases, thereby making bamboos both environmentally and ecologically benign [186]. Manandhar et al. [187] highlighted that bamboos are only sustainable construction materials provided that they are cultivated and harvested using sustainable practices, i.e., by employing a variety of harvesting cycles, which is healthy for the bamboo plantation. Moreover, because bamboo plantations can co-exist with other plantations, they offer added advantages for land economy and optimization. In addition, bamboos can be used for regenerating lands devasted by flood and deforestation and, with 
some species known to be drought-tolerant, it may be possible to cultivate bamboo plantations in large areas of dessert [188] that are ordinarily untended. Moreover, bamboos, as construction materials, demonstrate the lowest energy requirements and cost implications compared with conventional brick and concrete materials, with the added advantage of impacting positively on the local economy by creating both direct and indirect jobs [187].

Gasparatos et al. [189] posited that, in relation to the life cycle assessment (LCA) of biobased derived fuels, it would be naive to argue that a single classification of their impacts and sustainability will suffice, without considering further contributory factors such as an environmental and socioeconomic framework for current biobased processes and technologies. It was argued that these contributory factors are fundamental to delivering a well-rounded and unbiased assessment of the associated trade-offs and factors that lead to bioderived fuels being advocated. Hence, presenting a one-sided impact assessment without a comprehensive geopolitical consideration is unlikely to gain acceptance. In addition, there are no reliable processes to comprehensively demonstrate the environmental and socioeconomic impacts of bioderived fuels [190].

Bamboo plantations act as windbreakers, sun shields, air purifiers (providing 35\% more oxygen equivalents relative to trees), and carbon dioxide recyclers (an estimated 12 tons per hectare). Furthermore, they can control erosion to mitigate desertification, sustain watersheds, and mitigate the disappearance of wetlands (which are disappearing three times faster than forests) $[87,191]$. Typically, advancements in material science and engineering give rise to significant economic gains. These gains have associated benefits, such as the advancement in the standard of living, the enhancement of environmental quality, and a reduction in the demand for imported materials (thereby conserving scarce foreign exchange reserves), thus improving a nation's trade balance [192]. Therefore, a synergized and concerted collaboration between governments, industries, policymakers, and other key players along the bamboo-economy value-chain will create pathways for the mitigation of global warming, improved energy security, and the creation of jobs. This should correspond to a marked reduction in the dependence on fossil-based hydrocarbons and their derivatives, thus impacting global energy politics [193-195].

\section{Constraints on Lignocellulosic Biomass Optimization}

Among the top-ranking factors constraining lignocellulosic biomass optimization to produce value-added chemicals and fuels are the transmutation processes and technologies. Unlike the well-established petroleum chemistry and technological processes, the recalcitrant nature of lignocellulosic biomass stemming from its complex chemical constitution (i.e., the dissimilarity in the chemical compositions, structures, and reaction conditions of its components), interwoven connectivity via covalent bonds, and heterogeneity of feedstocks, presents severe challenges to attaining optimal yields for targeted products. Comparatively, the breakdown of lignin and hemicellulose is easier to achieve than cellulose, the decomposition and depolymerization of which can be challenging and energy-consuming. Moreover, the heterogeneity of bamboo biomass constituents, even within the same species, requires continuous adjustment of the pretreatment processes and technologies, thereby hampering process integration and resulting in high-cost implications. Further to the intricate and inert nature of lignocellulosic biomass, the constitutional ratios of elemental carbon, oxygen, and hydrogen inherent in lignocellulosic biomass present additional challenges in its chemocatalytic and enzymatic transmutation [46,196]. For example, Kabbour et al. [197] highlighted the challenges presented by the autocatalytic processes employed in lignocellulosic biomass valorization into furfural, which, they argued, are not convincing in terms of yield and selectivity. They further posited that although the use of biphasic systems shows promise, this process is limited by the difficulty of solvent recovery, thereby hampering the commercialization of these technologies. Similarly, Kawamoto [198] reported that pyrolysis-based (e.g., fast pyrolysis and gasification) technologies present promising pathways for the efficient and high-yield valorization of lignin into bioderived chemicals and materials. However, this study also asserted that more advanced research, especially 
in understanding the mechanisms and chemistry involved in lignin transmutation during pyrolysis/gasification technologies, which are in infant stages, may be significant in the development of the controlled pyrolysis and gasification processes in order to overcome the current limitations in product yield and selectivity [198].

Furthermore, the economy, availability, and cost of lignocellulosic biomass feedstocks for the production of materials, chemicals, and fuels is another hurdle facing the optimization of these processes. It is was reported that around 1 billion tons of lignocellulosic biomass are needed annually to compensate for about $30 \%$ of the petroleum consumption in the United States [199,200]. To put this into context, in 2012, only about 341 million tons of lignocellulosic biomass were readily available, with a projected estimate of 1.0-1.3 billion tons of lignocellulosic biomass expected to be readily available by 2030 [196], thereby highlighting a huge demand and supply gap. Other factors, such as soil requirements and climatic conditions, must also be considered in order for optimal cultivation to be achieved. Moreover, lignocellulosic biomass harvesting can be affected by issues ranging from machinery requirements, soil contamination, and moisture content during harvesting to logistical challenges (i.e., the supply chain), and different lignocellulosic biomasses require different harvesting methodologies, machinery, and pre-transportation treatments [201].

It is possible that, as bamboo plants gain global prominence as commercially viable crops, the challenge of navigating the risks of biodiversity depletion due to monocultures may need to be considered. In addition, the possibility of "cultivation abuse", such as the use of chemical fertilizers to enhance yields and increase profits, cannot be overlooked [202] Therefore, there is a requirement for international standardization to promulgate guidelines for bamboo lignocellulosic biomass resources, processing, and product derivation.

\section{Conclusions}

In the past, notable advancements have been made in the utilization of materials based on experiential knowledge of their characteristics and attributes in relation to their origin, treatment, and subsequent applications. These concepts are similarly invaluable in approaching the optimization of bamboo biomass, which is a critical component of strategies for achieving a circular economy and for the development and enhancement of sustainable materials. The utilization of bamboos in various applications and uses has been demonstrated as a potential alternative for timber, thereby presenting an opportunity for mitigating deforestation. In addition, bamboo grooves can also help in mitigating dessert encroachment, soil erosion control, and the preservation of vanishing wetlands, which are critical to Earth's ecosystems.

In addition to considering bamboo-derived hydrocarbons as benign alternatives to fossil-based hydrocarbons, not to mention the momentous role played by green vegetation in the oxygenation of the Earth and the subsequent radiation of life, it has been demonstrated that bamboos possess suppleness, are ecologically viable, exhibit performance in applications such as construction, and are sustainable. Hence, green vegetation such as bamboo plants presents an unrivalled opportunity for scientists and engineers to meet our current technological needs while not endangering the environment for future generations through the mass harnessing of solar energy. Moreover, it may not be unrealistic to optimize Earth's deserts for bamboo plantations and renewable biomass cultivation to mitigate challenges associated with land demand.

Author Contributions: Conceptualization, A.O.C.I. and S.S.R.; methodology, S.S.R.; software, A.O.C.I.; validation, S.S.R. and A.O.C.I.; formal analysis, S.S.R.; investigation, S.S.R. and A.O.C.I.; resources, S.S.R.; data curation, S.S.R.; writing-original draft preparation, A.O.C.I.; writing—review and editing, S.S.R.; visualization, A.O.C.I.; supervision, S.S.R.; project administration, S.S.R.; funding acquisition, S.S.R. All authors have read and agreed to the published version of the manuscript.

Funding: Council for Scientific and Industrial Research (HGER74p) and the Department of Science and Innovation (HGERA8x).

Conflicts of Interest: The authors declare no conflict of interest. 


\section{References}

1. Thomas, B. Biomineralization: An Engineering Masterpiece / The Institute for Creation Research. Available online: https: / / www.icr.org/article/4145 (accessed on 16 May 2020).

2. Coppens, M.O. A nature-inspired approach to reactor and catalysis engineering. Curr. Opin. Chem. Eng. 2012, 1, 281-289. [CrossRef]

3. Mattheck, C. Design in Nature-Learning from Trees; Linnard, W., Translator; Springer: Berlin/Heidelberg, Germany, 1998. [CrossRef]

4. Piekarski, K. Analysis of bone as a composite material. Int. J. Eng. Sci. 1973, 11, 557-558. [CrossRef]

5. Florida State University Australian Saltwater Crocodiles Are World's Most Powerful Biters. Available online: www.sciencedaily. com/releases/2012/03/120316093427.htm (accessed on 7 February 2020).

6. Saber, A.; Hassanin, A. Some Morphological Studies on the Jaw Joint of the Australian Saltwater Crocodile (Crocodylus porosus). J. Vet. Anat. 2014, 7, 55-74. [CrossRef]

7. Qu, D.; Mosher, C.Z.; Boushell, M.K.; Lu, H.H. Engineering Complex Orthopaedic Tissues Via Strategic Biomimicry. Ann. Biomed. Eng. 2015, 43, 697-717. [CrossRef] [PubMed]

8. Barba, A.; Diez-Escudero, A.; Espanol, M.; Bonany, M.; Sadowska, J.M.; Guillem-Marti, J.; Öhman-Mägi, C.; Persson, C.; Manzanares, M.C.; Franch, J.; et al. Impact of Biomimicry in the Design of Osteoinductive Bone Substitutes: Nanoscale Matters. ACS Appl. Mater. Interfaces 2019, 11, 8818-8830. [CrossRef]

9. Perera, A.S.; Coppens, M.O. Re-designing materials for biomedical applications: From biomimicry to nature-inspired chemical engineering. Philos. Trans. R. Soc. A Math. Phys. Eng. Sci. 2019, 377. [CrossRef]

10. Andersson, M.; Jia, Q.; Abella, A.; Lee, X.Y.; Landreh, M.; Purhonen, P.; Hebert, H.; Tenje, M.; Robinson, C.V.; Meng, Q.; et al. Biomimetic spinning of artificial spider silk from a chimeric minispidroin. Nat. Chem. Biol. 2017, 13, 262-264. [CrossRef] [PubMed]

11. Lewis, N.S. Toward cost-effective solar energy use. Science 2007, 315, 798-801. [CrossRef]

12. Lewis, N.S.; Crabtree, G.; Nozik, A.J.; Wasielewski, M.R.; Alivisatos, P.; Kung, H.; Tsao, J.; Chandler, E.; Walukiewicz, W.; Spitler, M.; et al. Basic Research Needs for Solar Energy Utilization. Report of the Basic Energy Sciences Workshop on Solar Energy Utilization, 18-21 April 2005. Available online: https:/ / doi.org/10.2172/899136 (accessed on 18 May 2020).

13. Lewis, N.S.; Crabtree, G. Basic Research Needs for Solar Energy Utilization; Argonne National Laboratory: Washington, DC, USA, 2005. Available online: http://www.sc.doe.gov/bes/reports/files/SEU_rpt.pdf (accessed on 20 May 2020).

14. Devabhaktuni, V.; Alam, M.; Shekara Sreenadh Reddy Depuru, S.; Green, R.C.; Nims, D.; Near, C. Solar energy: Trends and enabling technologies. Renew. Sustain. Energy Rev. 2013, 19, 555-564. [CrossRef]

15. Cho, C.; Nam, K.; Kim, G.Y.; Seo, Y.H.; Hwang, T.G.; Seo, J.W.; Kim, J.P.; Han, J.I.; Lee, J.Y. Multi-bandgap Solar Energy Conversion via Combination of Microalgal Photosynthesis and Spectrally Selective Photovoltaic Cell. Sci. Rep. 2019, 9. [CrossRef]

16. Gong, J.; Li, C.; Wasielewski, M.R. Advances in solar energy conversion. Chem. Soc. Rev. 2019, 48, 1862-1864. [CrossRef]

17. Kadoya, S.; Catling, D.C.; Nicklas, R.W.; Puchtel, I.S.; Anbar, A.D. Mantle data imply a decline of oxidizable volcanic gases could have triggered the Great Oxidation. Nat. Commun. 2020, 11, 2774. [CrossRef]

18. Planavsky, N.J.; Asael, D.; Hofmann, A.; Reinhard, C.T.; Lalonde, S.V.; Knudsen, A.; Wang, X.; Ossa Ossa, F.; Pecoits, E.; Smith, A.J.B.; et al. Evidence for oxygenic photosynthesis half a billion years before the Great Oxidation Event. Nat. Geosci. 2014, 7, 283-286. [CrossRef]

19. Hunt, J.M. Petroleum Geochemistry and Geology; W.H. Freeman: New York, NY, USA, 1996; ISBN 9780716724414.

20. Speight, J.G. The Chemistry and Technology of Petroleum, 5th ed.; CRC Press: Boca Raton, FL, USA, $2014 ;$ ISBN 9781439873892.

21. Norde, W. Energy and entropy: A thermodynamic approach to sustainability. Environmentalist 1997, 17, 57-62. [CrossRef]

22. Dennison, W.C. Environmental problem solving in coastal ecosystems: A paradigm shift to sustainability. Estuar. Coast. Shelf Sci. 2008, 77, 185-196. [CrossRef]

23. Kenney, J.F.; Krayushkin, V.A.; Karpov, I.K.; Kutcherov, V.G.; Plotnikova, I.N. Dismissal of the Claims of a Biological Connection for Natural Petroleum. Energia 2001, 22, 26-34.

24. Kenney, J.F.; Kutcherov, V.A.; Bendeliani, N.A.; Alekseev, V.A. The evolution of multicomponent systems at high pressures: VI. The thermodynamic stability of the hydrogen-carbon system: The genesis of hydrocarbons and the origin of petroleum. Proc. Natl. Acad. Sci. USA 2002, 99, 10976-10981. [CrossRef] [PubMed]

25. Vassiliou, M.S. The A to Z of the Petroleum Industry; Woronoff, J., Ed.; Scarecrow Press, Inc.: Lanham, MD, USA, 2009; ISBN 978-0-8108-7153-3.

26. Husain, A.T. Contentious Oil Politics and the Rentier State Theory. Pakistan Horiz. 2019, 72, 97-113.

27. Van de Graaf, T.; Sovacool, B.K.; Ghosh, A.; Kern, F.; Klare, M.T. States, Markets, and Institutions: Integrating International Political Economy and Global Energy Politics. 2016. Available online: https:/ /doi.org/10.1057/978-1-137-55631-8_1 (accessed on 5 August 2020).

28. Iroegbu, A.O.C.; Ray, S.S.; Mbarane, V.; Bordado, J.C.; Sardinha, J.P. Plastic Pollution: A Perspective on Matters Arising: Challenges and Opportunities. ACS Omega 2021, 6, 19343-19355. [CrossRef]

29. Ray, S.S.; Iroegbu, A.O.C. Nanocellulosics: Benign, Sustainable, and Ubiquitous Biomaterials for Water Remediation. ACS Omega 2021, 6, 4511-4526. [CrossRef] [PubMed]

30. Iroegbu, A.O.; Hlangothi, S.P. Furfuryl Alcohol a Versatile, Eco-Sustainable Compound in Perspective. Chem. Africa 2019, 2, 223-239. [CrossRef] 
31. Silvia, T.; Giorgio, G.; Francesco, M.; Giancarlo, C. Alternative Techniques and Sustainable Methods for the Valorisation of Lignocellulosic Biomass. In Biomass Burning in Sub-Saharan Africa; Mammino, L., Ed.; Springer: Dordrecht, The Netherlands, 2020; pp. 83-91. [CrossRef]

32. Watson, S.M. Greenhouse gas emissions from offshore oil and gas activities-Relevance of the Paris Agreement, Law of the Sea, and Regional Seas Programmes. Ocean Coast. Manag. 2020, 185. [CrossRef]

33. Umbach, F. Global energy security and the implications for the EU. Energy Policy 2010, 38, 1229-1240. [CrossRef]

34. Iroegbu, A.O.; Sadiku, E.R.; Ray, S.S.; Hamam, Y. Sustainable Chemicals: A Brief Survey of the Furans. Chem. Africa 2020, 3, 481-496. [CrossRef]

35. Binod, P.; Sindhu, R.; Janu, K.U.; Pandey, A. Hydrolysis of Cellulosic and Hemicellulosic Biomass. Biofuels Altern. Feed. Convers. Process. Prod. Liq. Gaseous Biofuels 2019, 447-460. [CrossRef]

36. Gogoi, S.; Bhuyan, N.; Sut, D.; Narzari, R.; Gogoi, L.; Kataki, R. Agricultural Wastes as Feedstock for Thermo-Chemical Conversion: Products Distribution and Characterization. Energy Recover. Process. Wastes 2020, 115-128. [CrossRef]

37. Yousuf, A.; Pirozzi, D.; Sannino, F. Fundamentals of lignocellulosic biomass. Lignocellul. Biomass Liq. Biofuels 2020, 1-15. [CrossRef]

38. Calvin, M. Photosynthesis As a Resource for Energy and Materials. Photochem. Photobiol. 1976, 23, 425-444. [CrossRef] [PubMed]

39. Calvin, M. Energy and Materials via Photosynthesis. In Living Systems as Energy Converters; Elsevier: Amsterdam, The Netherlands, 1977; pp. 231-259. [CrossRef]

40. Calvin, M. Petroleum Plantations for Fuel and Materials. Bioscience 1979, 29, 533-538. [CrossRef]

41. Guerriero, G.; Hausman, J.F.; Strauss, J.; Ertan, H.; Siddiqui, K.S. Lignocellulosic biomass: Biosynthesis, degradation, and industrial utilization. Eng. Life Sci. 2016, 16, 1-16. [CrossRef]

42. Lucia, L.A. Lignocellulosic Biomass: A Potential Feedstock To Replace Petroleum. BioResources 2008, 3, $981-982$.

43. Anwar, Z.; Gulfraz, M.; Irshad, M. Agro-industrial lignocellulosic biomass a key to unlock the future bio-energy: A brief review. J. Radiat. Res. Appl. Sci. 2014, 7, 163-173. [CrossRef]

44. Isikgor, F.H.; Becer, C.R. Lignocellulosic biomass: A sustainable platform for the production of bio-based chemicals and polymers. Polym. Chem. 2015, 6, 4497-4559. [CrossRef]

45. Tang, X.; Zeng, X.; Li, Z.; Hu, L.; Sun, Y.; Liu, S.; Lei, T.; Lin, L. Production of $\gamma$-valerolactone from lignocellulosic biomass for sustainable fuels and chemicals supply. Renew. Sustain. Energy Rev. 2014, 40, 608-620. [CrossRef]

46. Zhou, C.H.; Xia, X.; Lin, C.X.; Tong, D.S.; Beltramini, J. Catalytic conversion of lignocellulosic biomass to fine chemicals and fuels. Chem. Soc. Rev. 2011, 40, 5588-5617. [CrossRef] [PubMed]

47. Ojeda, K.; Sánchez, E.; Kafarov, V. Sustainable ethanol production from lignocellulosic biomass-Application of exergy analysis. Energy 2011, 36, 2119-2128. [CrossRef]

48. Maki, M.; Leung, K.T.; Qin, W. The prospects of cellulase-producing bacteria for the bioconversion of lignocellulosic biomass. Int. J. Biol. Sci. 2009, 5, 500-516. [CrossRef]

49. Lee, H.V.; Hamid, S.B.A.; Zain, S.K. Conversion of lignocellulosic biomass to nanocellulose: Structure and chemical process. Sci. World J. 2014, 2014. [CrossRef]

50. Du, H.; Liu, W.; Zhang, M.; Si, C.; Zhang, X.; Li, B. Cellulose nanocrystals and cellulose nanofibrils based hydrogels for biomedical applications. Carbohydr. Polym. 2019, 209, 130-144. [CrossRef] [PubMed]

51. Lum, W.C.; Lee, S.H.; Ahmad, Z.; Halip, J.A.; Chin, K.L. Lignocellulosic nanomaterials for construction and building applications Ind. Appl. Nanomater. 2019, 423-439. [CrossRef]

52. Rosales-Calderon, O.; Arantes, V. A review on commercial-scale high-value products that can be produced alongside cellulosic ethanol. Biotechnol. Biofuels 2019, 12. [CrossRef]

53. Zhou, Y.; Stanchev, P.; Katsou, E.; Awad, S.; Fan, M. A circular economy use of recovered sludge cellulose in wood plastic composite production: Recycling and eco-efficiency assessment. Waste Manag. 2019, 99, 42-48. [CrossRef]

54. Ray, S.S.; Iroegbu, A.O.C.; Bordado, J.C. Polymer-Based Membranes and Composites for Safe, Potable, and Usable Water: A Survey of Recent Advances. Chem. Africa 2020, 3, 593-608. [CrossRef]

55. Dunlop, A.P.; Peters, F.N. The Furans; Reinhold Publishing Corporation: New York, NY, USA, 1953.

56. Peters, F.N. The Furans Fifteen Years of Progress. Ind. Eng. Chem. 1936, 28, 755-759. [CrossRef]

57. Farhat, W.; Venditti, R.A.; Hubbe, M.; Taha, M.; Becquart, F.; Ayoub, A. A Review of Water-Resistant Hemicellulose-Based Materials: Processing and Applications. ChemSusChem 2017, 10, 305-323. [CrossRef] [PubMed]

58. Palaniappan, A.; Yuvaraj, S.S.; Sonaimuthu, S.; Antony, U. Characterization of xylan from rice bran and finger millet seed coat for functional food applications. J. Cereal Sci. 2017, 75, 296-305. [CrossRef]

59. Liu, X.; Lin, Q.; Yan, Y.; Peng, F.; Sun, R.; Ren, J. Hemicellulose from Plant Biomass in Medical and Pharmaceutical Application: A Critical Review. Curr. Med. Chem. 2018, 26, 2430-2455. [CrossRef]

60. Singh, S.; Varanasi, P.; Simmons, B. Renewable Aromatics from Lignocellulosic Lignin. US20150322214A1, 12 November 2015.

61. Ventura, M.; Domine, M.E.; Chávez-Sifontes, M. Catalytic Processes For Lignin Valorization into Fuels and Chemicals (Aromatics). Curr. Catal. 2019, 8, 20-40. [CrossRef]

62. Li, X.; Zheng, Y. Biotransformation of lignin: Mechanisms, applications and future work. Biotechnol. Prog. 2020, 36. [CrossRef] [PubMed] 
63. Kabir, A.; Cacciagrano, F.; Tartaglia, A.; Lipsi, M.; Ulusoy, H.I.; Locatelli, M. Analysis of monoterpenes and monoterpenoids. In Recent Advances in Natural Products Analysis; 2020; pp. 274-286. Available online: https:/ / doi.org/10.1016/b978-0-12-816455-6.0 0007-x (accessed on 20 March 2021).

64. Kabir, A.; Mocan, A.; Santoleri, M.; De Simone, M.; Cacciagrano, F.; Tartaglia, A.; Ulusoy, H.I.; Locatelli, M. Analysis of monophenols. In Recent Advances in Natural Products Analysis; 2020; pp. 19-37. Available online: https://doi.org/10.1016/b978-0 -12-816455-6.00002-0 (accessed on 22 June 2021).

65. Lorigooini, Z.; Jamshidi-kia, F.; Hosseini, Z. Analysis of aromatic acids (phenolic acids and hydroxycinnamic acids). In Recent Advances in Natural Products Analysis; 2020; pp. 199-219. Available online: https:/ / doi.org/10.1016/b978-0-12-816455-6.00004-4 (accessed on 20 June 2021).

66. Stevanovic, T. Chemistry of Lignocellulosics: Current Trends; Stevanovic, T., Ed.; A science publishers book; CRC Press: Boca Raton, FL, USA, 2018; ISBN 9781498775694.

67. Iroegbu, A.O.; Hlangothi, S.P. Effects of the Type of Catalyst on the Polymerisation Mechanism of Furfuryl Alcohol and its Resultant Properties. Chem. Afr. 2018, 1, 187-197. [CrossRef]

68. Zhao, C.; Shao, Q.; Chundawat, S.P.S. Recent advances on ammonia-based pretreatments of lignocellulosic biomass. Bioresour. Technol. 2020, 298. [CrossRef]

69. Verardi, A.; Lopresto, C.G.; Blasi, A.; Chakraborty, S.; Calabrò, V. Bioconversion of lignocellulosic biomass to bioethanol and biobutanol. Lignocellul. Biomass Liq. Biofuels 2020, 67-125. [CrossRef]

70. Ingle, A.P.; Chandel, A.K.; Antunes, F.A.F.; Rai, M.; da Silva, S.S. New trends in application of nanotechnology for the pretreatment of lignocellulosic biomass. Biofuels Bioprod. Biorefin. 2019, 13, 776-788. [CrossRef]

71. Ummalyma, S.B.; Supriya, R.D.; Sindhu, R.; Binod, P.; Nair, R.B.; Pandey, A.; Gnansounou, E. Biological pretreatment of lignocellulosic biomass-current trends and future perspectives. Second. Third Gener. Feed. Evol. Biofuels 2019, 197-212. [CrossRef]

72. Soares, J.F.; Confortin, T.C.; Todero, I.; Mayer, F.D.; Mazutti, M.A. Dark fermentative biohydrogen production from lignocellulosic biomass: Technological challenges and future prospects. Renew. Sustain. Energy Rev. 2020, 117. [CrossRef]

73. Bhatia, S.K.; Jagtap, S.S.; Bedekar, A.A.; Bhatia, R.K.; Patel, A.K.; Pant, D.; Rajesh Banu, J.; Rao, C.V.; Kim, Y.G.; Yang, Y.H. Recent developments in pretreatment technologies on lignocellulosic biomass: Effect of key parameters, technological improvements, and challenges. Bioresour. Technol. 2020, 300. [CrossRef] [PubMed]

74. World Economic Forum Top 10 Emerging Technologies. 2019. Available online: http://www3.weforum.org/docs/WEF_Top_10 _Emerging_Technologies_2019_Report.pdf (accessed on 22 June 2021).

75. Guinness World Records Fastest Growing Plant I Guinness World Records. Available online: https://www.guinnessworldrecords. com/world-records / fastest-growing-plant (accessed on 14 June 2020).

76. Ngounou, B. Central Africa: Inbar Promotes Bamboo and Rattan as an Alternative Wood. Available online: https://www.afrik21. africa/en/central-africa-inbar-promotes-bamboo-and-rattan-as-an-alternative-to-wood/ (accessed on 13 May 2020).

77. Bloodworth, D.; Bloodworth, C.P. The Chinese Machiavelli: 3000 Years of Chinese Statecraft; Routledge-Taylor and Francis Group: New York, NY, USA, 2017; ISBN 9780765805683.

78. Schreiber, M. To Know Bamboo is to Know Asia-And a Whole Lot of Japanese I The Japan Times. Available online: https: //www.japantimes.co.jp/life/2015/06/01/language/know-bamboo-know-asia-whole-lot-japanese/\#.XuLJfkUzbIV (accessed on 12 June 2020).

79. Freeman-Mitford, A.B. The Bamboo Garden; Macmillan \& Co., Ltd.: London, UK, 1896.

80. Hooker, J.D. Himalayan Journals; Or, Notes of a Naturalist in Bengal, the Sikkim and Nepal Himalayas, the Khasia Mountains, Ec.; Bettany, G.T., Ed.; Ward, Lock, Bowden and Co.: London, UK, 1891. [CrossRef]

81. Sulzberger, C. First edison lights at sea: The SS Columbia story, 1880-1907. IEEE Power Energy Mag. 2015, 13, 92-101. [CrossRef]

82. Abe, N. The Role of Bamboo in Japanese Culture. Available online: https:/ /www.thoughtco.com/bamboo-in-japanese-culture2028043 (accessed on 12 June 2020).

83. Wang, F.W. Fluidization mechanisms and motion simulation on flowslides triggered by earthquake and rainfall. Yanshilixue $Y u$ Gongcheng Xuebao/Chin. J. Rock Mech. Eng. 2005, 24, 1654-1661.

84. Nirmala, C.; Bisht, M.S.; Bajwa, H.K.; Santosh, O. Bamboo: A rich source of natural antioxidants and its applications in the food and pharmaceutical industry. Trends Food Sci. Technol. 2018, 77, 91-99. [CrossRef]

85. Satow, E.M. The Cultivation of Bamboos in Japan; Kelly \& Walsh Limited: Tokio, Japan, 1899; Volume 27.

86. Wimbush, S.H. The African Alpine Bamboo. Emp. For. J. 1945, 24, 33-39. [CrossRef]

87. Lucas, S. Bamboo; Liese, W.; Köhl, M. Tropical Forestry; Reaktion Books Ltd.: London, UK, 2013; Volume 10. [CrossRef]

88. Scurlock, J.M.O.; Dayton, D.C.; Hames, B. Bamboo: An overlooked biomass resource? Biomass Bioenergy 2000, 19, 229-244. [CrossRef]

89. Hidalgo-López, O. Bamboo-The Gift of the Gods; Bogotá, Colombia S.A.; O. Hidalgo-Lopez: Bogotá, Colombia, 2003; ISBN 958334298X.

90. Prakash, C. Bamboo fibre. In Handbook of Natural Fibres: Volume 1: Types, Properties and Factors Affecting Breeding and Cultivation; Kozłowski, R.M., Mackiewicz-Talarczyk, M., Eds.; Elsevier Ltd.: Amsterdam, The Netherlands, 2020; Volume 1, pp. 219-229. [CrossRef]

91. Tang, X.; Xia, M.; Pérez-Cruzado, C.; Guan, F.; Fan, S. Spatial distribution of soil organic carbon stock in Moso bamboo forests in subtropical China. Sci. Rep. 2017, 7. [CrossRef] [PubMed] 
92. Liew, F.K.; Hamdan, S.; Rahman, M.R.; Rusop, M.; Lai, J.C.H.; Hossen, M.F.; Rahman, M.M. Synthesis and characterization of cellulose from green bamboo by chemical treatment with mechanical process. J. Chem. 2015, 2015. [CrossRef]

93. Abdul Khalil, H.P.S.; Bhat, I.U.H.; Jawaid, M.; Zaidon, A.; Hermawan, D.; Hadi, Y.S. Bamboo fibre reinforced biocomposites: A review. Mater. Des. 2012, 42, 353-368. [CrossRef]

94. Wang, X.; Ren, H.; Zhang, B.; Fei, B.; Burgert, I. Cell wall structure and formation of maturing fibres of moso bamboo (Phyllostachys pubescens) increase buckling resistance. J. R. Soc. Interface 2012, 9, 988-996. [CrossRef] [PubMed]

95. Li, X.; Wei, Y.; Xu, J.; Xu, N.; He, Y. Quantitative visualization of lignocellulose components in transverse sections of moso bamboo based on FTIR macro- and micro-spectroscopy coupled with chemometrics. Biotechnol. Biofuels 2018, 11. [CrossRef]

96. Liese, W. Research on bamboo. Wood Sci. Technol. 1987, 21, 189-209. [CrossRef]

97. Wang, K.; Peng, H.; Lin, E.; Jin, Q.; Hua, X.; Yao, S.; Bian, H.; Han, N.; Pan, J.; Wang, J.; et al. Identification of genes related to the development of bamboo rhizome bud. J. Exp. Bot. 2010, 61, 551-561. [CrossRef]

98. Lobovikov, M.; Schoene, D.; Yping, L. Bamboo in climate change and rural livelihoods. Mitig. Adapt. Strateg. Glob. Chang. 2012, 17, 261-276. [CrossRef]

99. Shanmughavel, P.; Francis, K. Physiology of Bamboo; Shanmughavel, P., Francis, K., Eds.; Scientific Publishers: Coimbatore, India, 2001; ISBN 8172332742.

100. Yang, S.J.; Sun, M.; Zhang, Y.J.; Cochard, H.; Cao, K.F. Strong leaf morphological, anatomical, and physiological responses of a subtropical woody bamboo (Sinarundinaria nitida) to contrasting light environments. Plant. Ecol. 2014, 215, 97-109. [CrossRef]

101. Wang, S.; Zhan, H.; Li, P.; Chu, C.; Li, J.; Wang, C. Physiological Mechanism of Internode Bending Growth After the Excision of Shoot Sheath in Fargesia yunnanensis and Its Implications for Understanding the Rapid Growth of Bamboos. Front. Plant. Sci. 2020, 11. [CrossRef]

102. Akinlabi, E.T.; Anane-Fenin, K.; Akwada, D.R. Bamboo: The Multipurpose Plant; Springer Nature: Cham, Switzerland, 2017. [CrossRef]

103. Li, J.; Zheng, H.; Sun, Q.; Han, S.; Fan, B.; Yao, Q.; Yan, C.; Jin, C. Fabrication of superhydrophobic bamboo timber based on an anatase $\mathrm{TiO}_{2}$ film for acid rain protection and flame retardancy. RSC Adv. 2015, 5, 62265-62272. [CrossRef]

104. U.S. Patent Office. Report of the Commissioner of Patents for the Year 1864; Government Printing Office: Washington, DC, USA, 1866.

105. Nahar, K. A Review On Anti Odor Finishing Of Textiles, Its Application Method And Commercialization; University Politehnica Timisoara: Hunedoara, Romania, 2020.

106. Liu, L.; Wang, Q.; Cheng, L.; Qian, J.; Yu, J. Modification of natural bamboo fibers for textile applications. Fibers Polym. 2011, 12, 95-103. [CrossRef]

107. De Falco, F.; Gullo, M.P.; Gentile, G.; Di Pace, E.; Cocca, M.; Gelabert, L.; Brouta-Agnésa, M.; Rovira, A.; Escudero, R.; Villalba, R.; et al. Evaluation of microplastic release caused by textile washing processes of synthetic fabrics. Environ. Pollut. 2018, 236, 916-925. [CrossRef]

108. Carney Almroth, B.M.; Åström, L.; Roslund, S.; Petersson, H.; Johansson, M.; Persson, N.K. Quantifying shedding of synthetic fibers from textiles; a source of microplastics released into the environment. Environ. Sci. Pollut. Res. 2018, 25, 1191-1199. [CrossRef] [PubMed]

109. Kaur, V.; Chattopadhyay, D.; Kaur, S.; Kaur, M. Fibrous raw material of bamboo origin with improved fibrillation and spinnability. J. Text. Inst. 2019, 110, 832-837. [CrossRef]

110. Lee, S. Garment With Bamboo Fabric Liner. US008051495B2, 8 November 2011.

111. Ali, M.; Mahmood, A.H.; Hussain, S.; Ahmed, F. An Investigation into the Antibacterial Properties of Bamboo/Cotton Blended Fabric and Potential Limitations of the Test Method AATCC 147. J. Nat. Fibers 2019. [CrossRef]

112. Hardin, I.R.; Wilson, S.S.; Dhandapani, R.; Dhende, V. An assessment of the validity of claims for "Bamboo" fibers. Am. Assoc. Text. Chem. Color. Int. Conf. 2009, 9, 250-256.

113. Rathod, A.; Kolhatkar, K. Analysis of Physical Characteristics of Bamboo Fabrics. Int. J. Res. Eng. Technol. 2014, 3 , 21-25. [CrossRef]

114. Iqbal, M.I.; Mizan, R.A.; Khan, A.N. Bamboo Strips with Nodes: Composites Viewpoint. In Biofibers and Biopolymers for Biocomposites; 2020; pp. 159-169. Available online: https:/ / doi.org/10.1007/978-3-030-40301-0_7 (accessed on 22 June 2021).

115. Zhou, G.; Zhang, Z. A Kind of Infant Industry Produces the Fabric and Its Manufacturing Method of Environmental Protection and Economy Cool in Summer and Warm in Winter. CN109440241A. 8 March 2019. Available online: https://patents.google. com/patent/CN109440241A/en (accessed on 27 June 2020).

116. Abro, Z.A.; Chen, N.; Yifan, Z.; Cheng-Yu, H.; Abassi, A.M.R.; Simair, A.A.; Ahmed, R.; Hussain, A. Investigation on Thermal Comfort Characteristics of Regenerated Bamboo and Cotton Woven Structured Fabrics. Autex Res. J. 2018, 18. [CrossRef]

117. Basit, A.; Latif, W.; Baig, S.A.; Afzal, A. The Mechanical and Comfort Properties of Sustainable Blended Fabrics of Bamboo With Cotton and Regenerated Fibers. Cloth. Text. Res. J. 2018, 36, 267-280. [CrossRef]

118. Yang, Z.; Xu, S.; Ma, X.; Wang, S. Characterization and acetylation behavior of bamboo pulp. Wood Sci. Technol. 2008, 42, 621-632. [CrossRef]

119. Zhang, Y.; Peng, J. Clean Production Method for Bamboo Fibres. US20190264350A1, 29 August 2019.

120. Saravanan, K.; Prakash, C. Bamboo Fibers and Its Application in Textiles-An Overview. Available online: https://www.fibre2 fashion.com/industry-article/3788/bamboo-fibers-and-its-application-in-textiles-an-overview (accessed on 23 April 2020). 
121. Ławińska, K.; Serweta, W.; Gendaszewska, D. Applications of bamboo textiles in individualised children's footwear. Fibres Text. East. Eur. 2018, 26, 87-92. [CrossRef]

122. Textile World Not Your Run-of-the-Mill Bandage. Available online: https://www.textileworld.com/textile-world/features/2008 /03/not-your-run-of-the-mill-bandage/ (accessed on 23 June 2020).

123. Jhatial, A.K.; Khatri, A.; Ali, S.; Babar, A.A. Sol-gel finishing of bamboo fabric with nanoparticles for water repellency, soil release and UV resistant characteristics. Cellulose 2019, 26, 6365-6378. [CrossRef]

124. Ławińska, K.; Serweta, W.; Jaruga, I.; Popovych, N. Examination of selected upper shoe materials based on bamboo fabrics. Fibres Text. East. Eur. 2019, 27, 85-90. [CrossRef]

125. Napper, I.E.; Thompson, R.C. Release of synthetic microplastic plastic fibres from domestic washing machines: Effects of fabric type and washing conditions. Mar. Pollut. Bull. 2016, 112, 39-45. [CrossRef] [PubMed]

126. Iroegbu, A.O.C.; Sadiku, R.E.; Ray, S.S.; Hamam, Y.; Sadiku, E.R.; Ray, S.S.; Hamam, Y. Plastics in municipal drinking water and wastewater treatment plant effluents: Challenges and opportunities for South Africa-A review. Environ. Sci. Pollut. Res. 2020, 27. [CrossRef] [PubMed]

127. Okubo, K.; Fujii, T.; Yamamoto, Y. Development of bamboo-based polymer composites and their mechanical properties. Compos. Part. A Appl. Sci. Manuf. 2004, 35, 377-383. [CrossRef]

128. Lam, S.S.; Azwar, E.; Peng, W.; Tsang, Y.F.; Ma, N.L.; Liu, Z.; Park, Y.K.; Kwon, E.E. Cleaner conversion of bamboo into carbon fibre with favourable physicochemical and capacitive properties via microwave pyrolysis combining with solvent extraction and chemical impregnation. J. Clean. Prod. 2019, 236. [CrossRef]

129. Wang, F.; Shao, J.; Keer, L.M.; Li, L.; Zhang, J. The effect of elementary fibre variability on bamboo fibre strength. Mater. Des. 2015, 75, 136-142. [CrossRef]

130. Fuentes, C.A.; Tran, L.Q.N.; Dupont-Gillain, C.; Vanderlinden, W.; De Feyter, S.; Van Vuure, A.W.; Verpoest, I. Wetting behaviour and surface properties of technical bamboo fibres. Colloids Surf. A Physicochem. Eng. Asp. 2011, 380, 89-99. [CrossRef]

131. Landis, C.M.; Beyerlein, I.J.; McMeeking, R.M. Micromechanical simulation of the failure of fiber reinforced composites. J. Mech. Phys. Solids 2000, 48, 621-648. [CrossRef]

132. Roslan, S.A.H.; Hassan, M.Z.; Rasid, Z.A.; Ibrahim, H.I. Tensile behaviour of chemical treatment for bamboo epoxy composites. Chem. Eng. Trans. 2018, 63, 745-750. [CrossRef]

133. Depuydt, D.E.C.; Soete, J.; Asfaw, Y.D.; Wevers, M.; Ivens, J.; van Vuure, A.W. Sorption behaviour of bamboo fibre reinforced composites, why do they retain their properties? Compos. Part. A Appl. Sci. Manuf. 2019, 119, 48-60. [CrossRef]

134. Biobased News Europe the BAMCO Consortium. Available online: http://news.bio-based.eu/the-bamco-consortium/ (accessed on 27 June 2020).

135. Mofidi, A.; Abila, J.; Ng, J.T.M. Novel advanced composite bamboo structural members with bio-based and synthetic matrices for sustainable construction. Sustainability 2020, 12, 2485. [CrossRef]

136. Mekonnen, B.Y.; Mamo, Y.J. Tensile and Flexural Analysis of a Hybrid Bamboo/Jute Fiber-reinforced Composite with Polyester Matrix as a Sustainable Green Material for Wind Turbine Blades. Int. J. Eng. 2020, 33, 1-6. [CrossRef]

137. Bamboo Bicycles Beijing \& Beyond. Available online: http:/ / www.bamboobicyclesbj.com/ (accessed on 30 June 2020).

138. Innovation, H. Bamboo Bike Beijing: Sustainable Bicycles with Bamboo as a Natural Lightweight Material. Available online: http:/ / www.haute-innovation.com/de/magazin/nachhaltigkeit/bamboo-bike-beijing-sustainable-bicycles.html (accessed on 30 June 2020).

139. University of Cambridge Visualizing Heat Flow in Bamboo Could Help Design More Energy-Efficient and Fire-Safe Buildings. Available online: https:/ / phys.org/news/2019-11-visualizing-bamboo-energy-efficient-fire-safe.html (accessed on 30 June 2020).

140. Shah, D.U.; Konnerth, J.; Ramage, M.H.; Gusenbauer, C. Mapping thermal conductivity across bamboo cell walls with scanning thermal microscopy. Sci. Rep. 2019, 9. [CrossRef]

141. Owano, N. Sports Hall for School in Thailand Has Bamboo Construction. Available online: https://techxplore.com/news/2017 -08-sports-hall-school-thailand-bamboo.html (accessed on 2 July 2020).

142. Harries, K.A.; Trujillo, D. Taking Action on Bamboo in the Urban Environment. In Proceedings of the Pittsburgh Declaration, Pittsburgh, PA, USA, 4-6 May 2016; pp. 1-4.

143. Durrell, J. Construction Experts at University of Pittsburgh Symposium Call for Bamboo to Become 21st Century Building Material. Available online: https://phys.org/news/2016-05-experts-university-pittsburgh-symposium-bamboo.html (accessed on 2 July 2020).

144. Worrell, G. Bamboo Lights a Fire under Australian Construction Industry. Available online: https://techxplore.com/news/2019 -09-bamboo-australian-industry.html (accessed on 2 July 2020).

145. Bamboo Ceiling in Madrid International Airport I MOSO Bamboo Specialist. Available online: https:/ / www.moso-bamboo. com/bamboo-inspiration/madrid-international-airport/?lang_selected=true (accessed on 2 July 2020).

146. Archila, H.; Kaminski, S.; Trujillo, D.; Zea Escamilla, E.; Harries, K.A. Bamboo reinforced concrete: A critical review. Mater. Struct. Constr. 2018, 51, 102. [CrossRef]

147. Qaiser, S.; Hameed, A.; Alyousef, R.; Aslam, F.; Alabduljabbar, H. Flexural strength improvement in bamboo reinforced concrete beams subjected to pure bending. J. Build. Eng. 2020, 31. [CrossRef]

148. Odeyemi, S.O.; Abdulwahab, R.; Bello, S.A.; Omoniyi, A.O.; Adeniyi, A.G. Repair of Flexural Damaged Reinforced Concrete Beams Using Embedded Bamboo Reinforced Epoxy Composite. Malays. J. Civ. Eng. 2020, 32, 13-18. [CrossRef] 
149. He, J.; Cui, S.; Wang, S.Y. Preparation and crystalline analysis of high-grade bamboo dissolving pulp for cellulose acetate. J. Appl. Polym. Sci. 2008, 107, 1029-1038. [CrossRef]

150. Wang, L. Evaluation of Properties of Natural Bamboo Fiber for Application in Summer Textiles. J. Fiber Bioeng. Inform. 2010, 3 , 94-99. [CrossRef]

151. Sathitsuksanoh, N.; Zhu, Z.; Ho, T.J.; Der Bai, M.; Zhang, Y.H.P. Bamboo saccharification through cellulose solvent-based biomass pretreatment followed by enzymatic hydrolysis at ultra-low cellulase loadings. Bioresour. Technol. 2010, 101, 4926-4929. [CrossRef] [PubMed]

152. Kuttiraja, M.; Sindhu, R.; Varghese, P.E.; Sandhya, S.V.; Binod, P.; Vani, S.; Pandey, A.; Sukumaran, R.K. Bioethanol production from bamboo (Dendrocalamus sp.) process waste. Biomass Bioenergy 2013, 59, 142-150. [CrossRef]

153. Yasuda, M.; Takeo, K.; Matsumoto, T.; Shiragami, T.; Sugamoto, K.; Matsushita, Y.; Ishii, Y. Effectiveness of Lignin-Removal in Simultaneous Saccharification and Fermentation for Ethanol Production from Napiergrass, Rice Straw, Silvergrass, and Bamboo with Different Lignin-Contents. In Sustainable Degradation of Lignocellulosic Biomass-Techniques, Applications and Commercialization; 2013. Available online: https:/ / doi.org/10.5772/54194 (accessed on 26 October 2021).

154. Yamashita, Y.; Shono, M.; Sasaki, C.; Nakamura, Y. Alkaline peroxide pretreatment for efficient enzymatic saccharification of bamboo. Carbohydr. Polym. 2010, 79, 914-920. [CrossRef]

155. Leenakul, W.; Tippayawong, N. Dilute acid pretreatment of bamboo for fermentable sugar production. J. Sustain. Energy Environ. 2010, 2010, 117-120.

156. Littlewood, J.; Wang, L.; Turnbull, C.; Murphy, R.J. Techno-economic potential of bioethanol from bamboo in China. Biotechnol. Biofuels 2013, 6. [CrossRef]

157. Li, Y.; Zhang, J.; Chang, S.X.; Jiang, P.; Zhou, G.; Fu, S.; Yan, E.; Wu, J.; Lin, L. Long-term intensive management effects on soil organic carbon pools and chemical composition in Moso bamboo (Phyllostachys pubescens) forests in subtropical China. For. Ecol. Manage. 2013, 303, 121-130. [CrossRef]

158. Klemm, D.; Heublein, B.; Fink, H.P.; Bohn, A. Cellulose: Fascinating biopolymer and sustainable raw material. Angew. Chemie. 2005, 44, 3358-3393. [CrossRef]

159. Lejeune, A.; Deprez, T. Cellulose: Structure and Properties, Derivatives and Industrial Uses (Biotechnology in Agriculture, Industry and Medicine Series 2010); Nova Science Publishers: New York, NY, USA, 2010; ISBN 9781608763887.

160. Cross, C.F.; Bevan, E.J.; Beadle, C. Plastic Compound of Cellulose. US520770A, 20 April 1894.

161. Winter, A.G. Method of Fireproofing Cellulose. US655845A, 14 August 1900.

162. Wang, D. A critical review of cellulose-based nanomaterials for water purification in industrial processes. Cellulose 2019, 26, 687-701. [CrossRef]

163. Song, N.; Hou, X.; Chen, L.; Cui, S.; Shi, L.; Ding, P. A Green Plastic Constructed from Cellulose and Functionalized Graphene with High Thermal Conductivity. ACS Appl. Mater. Interfaces 2017, 9, 17914-17922. [CrossRef] [PubMed]

164. Jiao, L.; Su, M.; Chen, L.; Wang, Y.; Zhu, H.; Dai, H. Natural cellulose nanofibers as sustainable enhancers in construction cement. PLoS ONE 2016, 11, e0168422. [CrossRef]

165. Abdelhamid, A.E.; Khalil, A.M. Polymeric membranes based on cellulose acetate loaded with candle soot nanoparticles for water desalination. J. Macromol. Sci. Part. A Pure Appl. Chem. 2019, 56, 153-161. [CrossRef]

166. Peng, F.; Ren, J.L.; Xu, F.; Sun, R.C. Chemicals from hemicelluloses: A review. ACS Symp. Ser. 2011, 1067, 219-259. [CrossRef]

167. Karunarathna, M.S.; Smith, R.C. Valorization of lignin as a sustainable component of structural materials and composites: Advances from 2011 to 2019. Sustainability 2020, 12, 734. [CrossRef]

168. Serrano, L.; Luque, R.; Sels, B.F. (Eds.) Lignin Chemistry; Topics in Current Chemistry Collections; Springer International Publishing: Berlin/Heidelberg, Germany, 2020; ISBN 978-3-030-00589-4.

169. Yadav, V.G. Biovalorization of lignin. Chem. Eng. Trans. 2020, 80, 283-288. [CrossRef]

170. Liu, S.; Ma, M.G. Lignin-derived nitrogen-doped polyacrylonitrile/polyaniline carbon nanofibers by electrospun method for energy storage. Ionics 2020. [CrossRef]

171. Trimble, W. On charring wood. Plough Loom Anvil 1851, 3, 513-516.

172. Retan, G. Charcoal as a Means of Solving Some Nursery Problems. J. For. 1915, 13, 25-30. [CrossRef]

173. Lehmann, J.; Joseph, S. (Eds.) Biochar for Environmental Management, 2nd ed.; Taylor \& Francis: London, UK, 2015. [CrossRef]

174. Chen, D.; Yu, X.; Song, C.; Pang, X.; Huang, J.; Li, Y. Effect of pyrolysis temperature on the chemical oxidation stability of bamboo biochar. Bioresour. Technol. 2016, 218, 1303-1306. [CrossRef]

175. Xu, T.; Lou, L.; Luo, L.; Cao, R.; Duan, D.; Chen, Y. Effect of bamboo biochar on pentachlorophenol leachability and bioavailability in agricultural soil. Sci. Total Environ. 2012, 414, 727-731. [CrossRef] [PubMed]

176. Liu, N.; Zhou, J.; Han, L.; Ma, S.; Sun, X.; Huang, G. Role and multi-scale characterization of bamboo biochar during poultry manure aerobic composting. Bioresour. Technol. 2017, 241, 190-199. [CrossRef] [PubMed]

177. Duan, Y.; Awasthi, S.K.; Chen, H.; Liu, T.; Zhang, Z.; Zhang, L.; Awasthi, M.K.; Taherzadeh, M.J. Evaluating the impact of bamboo biochar on the fungal community succession during chicken manure composting. Bioresour. Technol. 2019, 272, 308-314. [CrossRef]

178. Wang, Y.; Lu, J.; Wu, J.; Liu, Q.; Zhang, H.; Jin, S. Adsorptive removal of fluoroquinolone antibiotics using bamboo biochar. Sustainability 2015, 7, 12947-12957. [CrossRef] 
179. Gu, X.; Wang, Y.; Lai, C.; Qiu, J.; Li, S.; Hou, Y.; Martens, W.; Mahmood, N.; Zhang, S. Microporous bamboo biochar for lithium-sulfur batteries. Nano Res. 2014, 8, 129-139. [CrossRef]

180. Wei, Y.; Yan, Y.; Zou, Y.; Shi, M.; Deng, Q.; Zhao, N.; Wang, J.; You, C.; Yang, R.; Xu, Y. Sulfonated polyaniline coated bambooderived biochar/sulfur cathode for Li-S batteries with excellent dual conductivity and polysulfides affinity. Electrochim. Acta 2019, 310, 45-57. [CrossRef]

181. Ren, Q.; Zeng, Z.; Jiang, Z.; Li, H. Functionalization of renewable bamboo charcoal to improve indoor environment quality in a sustainable way. J. Clean. Prod. 2020, 246. [CrossRef]

182. Xu, Y.; Zhang, C.; Kuang, S.; Zhao, K.; Chen, M.; Xu, D.; Chen, W.; Yu, X. Facile synthesis and electrochemical performances of activated bamboo charcoal supported $\mathrm{MoS}_{2}$ nanoflakes as anodes materials for lithium-ion batteries. J. Electroanal. Chem. 2019, 847. [CrossRef]

183. Thakur, A.; Ganeshpurkar, A.; Jaiswal, A. Charcoal in Dentistry. In Natural Oral Care in Dental Therapy; Chauhan, D.N., Singh, P.R., Shah, K., Chauhan, N.S., Eds.; Wiley: Hoboken, NJ, USA, 2020; pp. 197-209. [CrossRef]

184. MOSO Applications I MOSO®Bamboo Specialist. Available online: https:/ / www.moso-bamboo.com/applications / (accessed on 9 July 2020).

185. Azeez, M.A.; Orege, J.I. Bamboo, Its Chemical Modification and Products. In Bamboo-Current and Future Prospects; 2018. Available online: https: / / doi.org/10.5772/intechopen.76359 (accessed on 12 May 2021).

186. Poppens, R.P.; van Dam, J.E.G.; Elbersen, H. Bamboo: Analyzing the Potential of Bamboo Feedstock for the Biobased Economy; Minsitry of Economic Affairs: The Hague, The Netherlands, 2013.

187. Manandhar, R.; Kim, J.H.J.T.; Kim, J.H.J.T. Environmental, social and economic sustainability of bamboo and bamboo-based construction materials in buildings. J. Asian Archit. Build. Eng. 2019, 18, 52-62. [CrossRef]

188. Basumatary, A.; Middha, S.K.; Usha, T.; Brahma, B.K.; Goyal, A.K. Bamboo, as Potential Sources of Food Security, Economic Prosperity and Ecological Security in North-East India: An Overview. Res. Plant. Biol. 2015, 5, 17-23.

189. Gasparatos, A.; Stromberg, P.; Takeuchi, K. Sustainability impacts of first-generation biofuels. Anim. Front. 2013, 3, 12-26. [CrossRef]

190. Gasparatos, A.; Lehtonen, M.; Stromberg, P. Do we need a unified appraisal framework to synthesize biofuel impacts? Biomass Bioenergy 2013, 50, 75-80. [CrossRef]

191. World's Wetlands Disappearing Three Times Faster than Forests I WWF. Available online: https://wwf.panda.org/wwf_news/?3 35575/Worlds-wetlands-disappearing-three-times-faster-than-forests (accessed on 8 July 2020).

192. National Research Council. Materials and Man's Needs: Materials Science and Engineering-Volume I, The History, Scope, and Nature of Materials Science and Engineering; The National Academies Press: Washington, DC, USA, 1975. [CrossRef]

193. McSwain, J.B. The Politics of the Global Oil Industry: An Introduction. Hist. Rev. New Books 2006, 34. [CrossRef]

194. Simon, C.A. Alternative Energy: Political, Economic, and Social Feasibility, 2nd ed.; Rowman \& Littlefield: Lanham, MD, USA, 2020; ISBN 9781538116371.

195. Van Meerbeek, K.; Muys, B.; Hermy, M. Lignocellulosic biomass for bioenergy beyond intensive cropland and forests. Renew. Sustain. Energy Rev. 2019, 102, 139-149. [CrossRef]

196. Balan, V. Current Challenges in Commercially Producing Biofuels from Lignocellulosic Biomass. ISRN Biotechnol. 2014, 2014, 1-31. [CrossRef]

197. Kabbour, M.; Luque, R. Furfural as a platform chemical. In Biomass, Biofuels, Biochemicals; Elsevier: Amsterdam, The Netherlands, 2020; pp. 283-297. [CrossRef]

198. Kawamoto, H. Lignin pyrolysis reactions. J. Wood Sci. 2017, 63, 117-132. [CrossRef]

199. Perlack, R.D.; Wright, L.L.; Turhollow, A.F.; Graham, R.L. Biomass as Feedstock for a Bioenergy and Bioproducts Industry: The Technical Feasibility of a Billion-Ton Annual Supply. 2005. Available online: https://www1.eere.energy.gov/bioenergy/pdfs/ final_billionton_vision_report2.pdf (accessed on 26 October 2021).

200. Oak Ridge National Laboratory. US Billion Ton Update: Biomass Supply for a Bioenergy and Bioproducts Industry (Executive Summary). 2011, 7. Available online: https:/ / doi.org/10.1089/ind.2011.7.375 (accessed on 11 July 2021).

201. Truong, H.; Le, T.M.A. Overview of Bamboo Biomass for Energy Production. 2014. Available online: https://halshs.archivesouvertes.fr/halshs-01100209/document (accessed on 22 June 2021).

202. Carter, K. The Ethical Wardrobe: Is Bamboo an Ethical Fabric? / Fashion I The Guardian. Available online: https://www. theguardian.com/lifeandstyle/2008/aug/13/bamboo.fabric (accessed on 8 July 2020). 